\title{
Peasant Mode of Production and the Evolution of Clientelar Relations
}

\author{
Laura da Graca
}

In order to characterise the relatively autonomous peasant societies that predominated in the early Middle Ages after the collapse of the state, Chris Wickham has proposed the concept of 'peasant mode of production.' This concept refines his earlier category of 'peasant-based society', which the author presented as 'deliberately anodyne', better than the notions of 'tribal', 'primitive communal' or 'kin-based' societies, less naïve and restricted than that of 'Germanic society' inspired in Tacitus, and close to that of 'rank society' by reason of its distinctness from societies with class antagonism, which it shares with the former types, and its clearer recognition of internal hierarchies. ${ }^{2}$ This perspective has furnished a paradigm for the analysis of the early Middle Ages societies as parts of a coherent whole, which justifies a reworking of the category of peasantbased society in terms of mode of production, a task undertaken by Wickham in Framing the Early Middle Ages (a peasant-based society would be a social formation dominated by the peasant mode of production). However, the author's theoretical approach has had less of an impact than his achievements in the field of comparative studies and empirical research.

Although he proposes a new mode of production, Wickham does not go to great lengths in order to formulate its contents in the language of historical materialism and the traditions he admittedly draws from (mainly economic anthropology). The way the issue is presented - coupled with the mistrust with which a new mode of production is regarded - undoubtedly have had some bearing on the adoption of the concept by Marxist historians, who prefer the less precise but broader concept of peasant-based society. In order to contribute to an assessment of Wickham's proposal, the first section of this analysis will

1 Wickham 2005, pp. 535-50. For a summarised account of Wickham's concept of the peasant mode of production, see 'Passages to Feudalism in Medieval Scandinavia' in this book. I would like to express my gratitude to Chris Wickham, Carlos Astarita and Octavio Colombo for their comments on this text.

2 Wickham 1994d, pp. 216-17. 
attempt a systematisation of the concept of the peasant mode of production. Given that the peasant mode, considered in isolation, corresponds to classless societies, we will follow Godelier's guidelines on the components of a mode of production in 'primitive' societies, i.e. the elements that must be encompassed in the concept, or else the aspects to be studied when determining the mode or modes of production in a given society. Some traits of the peasant mode not explicitly stated by Wickham have been gleaned through deduction; others are inferred from the development of empirical cases, Malling's imaginary village among others, where the author exemplifies the proposed concept and his general paradigm for analysis. ${ }^{3}$ In this sense, since we will refer to empirical examples, Wickham's methodological perspective on the peasant mode as an ideal type will be replaced by another one in which the concept shall be reconstructed as a real abstraction, that is to say, not as a model but as a structure of reality. ${ }^{4}$ This reconstruction, though based on Wickham's data, is still interpretive; indeed, the analysis yields elements not taken for granted (or even rejected) by the author, for example, the centrality of the Germanic mode of the Formen as property type.

We will then address the problem of clientelar relations between members of the feudal aristocracy and the peasantry, which in Wickham's proposal constitutes the main articulation mechanism between modes of production and a vehicle for the transformation of peasant societies. We will avail ourselves of the benefactoria, a documented form of patronage found in the North of Spain during the eleventh and twelfth centuries, in order to examine how clientelar bonds underwent a transformation into relations of exploitation. ${ }^{5}$ We will posit that these bonds express social practices derived from the peasant mode, and that while they preserve their original appearance, their content tends to become subordinate to the dominant feudal logic of the area. Our analysis suggests that this transformation, which goes through different stages,

3 Wickham 2005, pp. 428-34.

4 These criteria are in Dhoquois 1973, among others. The use of ideal types has been criticised in da Graca 2008, where it is argued that the manner in which the universal term is elaborated may condition the exploration of phenomena and the conclusions drawn from the analysis. This is apparent, for instance, in Wickham's assessment of aristocratic wealth levels in Northern France based on an ideal type of 'aristocracy', which leads him to emphasise nominal landowning over effective exploitation of lands.

5 The benefactoria has been considered as a lax social relation, in general terms, by Sánchez Albornoz 1976a and Estepa Díez 2003, pp. 39-80; a different approach appears in Martínez Sopena 1987, pp. 50 ff., and Martínez García 2008, who equates servitium with serfdom. On the ambivalent meaning of the word servitium in the early Middle Ages, see Davis 1996, pp. 227-8. 
is one of the mechanisms for feudal expansion over free spaces, and that the slow pace of change and its concrete manifestations result from the relative validity of the functioning principles of the peasant mode.

Some critics of the concept of the peasant mode of production have found it lacking in its ability to explain the change toward the dominance of another mode of production, and they have alleged that Wickham has not proved in a satisfactory manner how this transformation occurs. ${ }^{6}$ Notwithstanding that opinion, it will be demonstrated herein that the implied dynamic of the peasant mode can explain structural change and the manners in which it occurs, and that the process can be documented.

In order to further our analysis of social practice, we will resort to the information about peasant societies contained in 'family sagas.?

\section{Wickham's Concept of the Peasant Mode of Production}

According to Godelier's synthesis, the analysis of a society in terms of its mode of production must account for the productive forces that converge into the productive process and for the relations of production implicit in such process. ${ }^{8}$ In the Formen, this criterion is subordinated to a specific form of property:

Now this unity, which in one sense appears as the particular form of property, has its living reality in a specific mode of production itself, and this appears equally as the relationship of the individuals to one another and as their specific daily behaviour towards inorganic nature, their specific mode of labour (which is always family labour and often communal labour). ${ }^{9}$

6 Davidson 2011; Harman 2011.

7 On the historical value of Icelandic sagas, see Chris Wickham's chapter in this book.

8 Godelier 1974c.

9 Marx 1964, p. 94. Hindess and Hirst 1975, p. 125, follow these criteria: 'mode of production $=$ an articulated combination of specific mode of appropriation of the social product and a specific mode of appropriation of nature. A mode of production is a complex unity of relations and forces of production: the mode of appropriation of the product is determined by the relations of production, that is, by the social distribution of the means of production, and by the distribution of the agents to definite positions (labourers, non-labourers) as a function of the former distribution'. 
In keeping with Godelier's approach, the study of a mode of production must be grounded in the analysis of the production process of the dominant branch of production, which in turn necessitates establishing the features of the unit of production and the domestic group, the social forms of labour (cooperation and division of labour), the technical development of the means of labour, and an estimation of productivity and intensity of labour, considering an untapped productive potential, the conditions for its mobilisation and the demography associated with the development of productive forces; the examination must identify the mode of appropriation of the conditions of production and the social product, which is expressed in a specific form of property, as well as the form of circulation of products, which is a result of the social relations. ${ }^{10}$ Lastly, the structural analysis must uncover the internal logic of the mode of production, that is to say, the laws that govern its functioning, and the historical conditions of its genesis, reproduction and transformation (in the case of 'primitive' societies, the emergence of relations of exploitation). ${ }^{11}$ For the study of societies presenting more than one mode of production, Godelier resorts to the concept of social formation, which in his view calls for ascertaining both the manner of articulation among modes of production and which is the dominant one. ${ }^{12}$

Let us proceed to explore the features of the peasant mode of production based on this analytical scheme. In the peasant mode, the main productive activity is agriculture and that is its starting point, as opposed to other analog-

Godelier 1974c. Demography is included in the analysis of a mode of production in Marx 1965, p. 438: "The labouring population therefore produces, along with the accumulation of capital produced by it, the means by which it itself is made relatively superfluous, is turned into a relative surplus population; and it does this to an always increasing extent. This is a law of population peculiar to the capitalist mode of production; and in fact every special historic mode of production has its own laws of population, historically valid within its limits alone'.

11 Godelier 1974a. Kuchenbuch and Michael 1977 offer a similar scheme for the analysis of a mode of production, with the variations inherent to a class society. The analysis begins with an examination of the productive forces which are applied in the production process; the form in which producers are combined with the means of production determines the form of surplus appropriation; this is expressed in specific property relations, which in turn shape a particular class structure [ständische Klassen] because of the role played by political coercion in social reproduction; exchange is considered as logically derived from social relations; finally, the analysis of the feudal mode of production accounts for its transformation (the arising of capitalist social relations). Godelier 1974c. For further development of this approach to the notion of social formation, see Glucksmann 1973 . 
ous concepts which do not exclude pastoral-nomad or hunter-gatherer societies, such as Sahlins's domestic mode of production..$^{13}$ Land is the most important means of production and the labour force comes mainly from the members of the family. The unit of production is the individual household, which controls the conditions of production. The prevailing division of labour is that which is established naturally by gender and generation within the household, and there exist forms of simple cooperation whose development depends on the settlement patterns. Complex forms of cooperation are limited, as well as craft specialisation. The household consists basically of one nuclear family, and it includes non-family members (free or unfree servants) who fulfil auxiliary functions or collaborate in agricultural tasks without implying a withdrawal from productive work for the other members of the household. ${ }^{14}$ This circumstance precludes from positing a situation of class-exploitation within the household.

In the peasant mode, agricultural technology is relatively simple and the intensity of labour is low because there are no social reasons for the intensive use of the productive forces. ${ }^{15}$ Sahlins's principles with regard to the low productive intensity of the domestic mode of production apply, and these are in turn based on Chayanov's premise that the labour force of the peasant household is not fully tapped. ${ }^{16}$ This issue has been addressed by Ester Boserup, who associates agricultural intensification with demographic growth. Boserup observes that primitive cultivators (a) work fewer hours and less regularly than their counterparts in densely populated regions; (b) do not consider agricultural work as pleasant, limiting it to the minimum necessary; (c) are generally not unaware of the existence of more sophisticated tools and alternative cultivation methods whose application would imply an intensification of labour

13 Sahlins 1972.

14 This situation is verified in medieval Iceland, which is the main reference used in the construction of the concept of the peasant mode. See Karras 1988, p. 81.

15 Both Davidson 2011, p. 91, and Harman 2011, p. 104 suggest a parallel between the functioning of the peasant mode and Brenner's conception of feudal peasantry, according to which the predominance of rules of economic behaviour that are contrary to innovation determines the impossibility of an internal transformational dynamic. Davidson infers that the concept of the peasant mode (as well as Brenner's notion of feudalism) cannot explain the change toward another mode of production. For Harman, even classless societies present developments in their productive forces that may precipitate structural change, and in his view the level of productive forces in the peasant mode resembles more that of the class societies with which it coexists.

16 Sahlins 1972, pp. 87-92. 
they deem inconvenient; (d) prefer to forgo those options unless population growth threatens subsistence. In conclusion, there is a margin for intensifying production in response to population growth (or the introduction of relations of exploitation). ${ }^{17}$ These premises lead to a demography that is specific to the peasant mode which implies an untapped surplus that can be mobilised in situations of demographic pressure, something that peasant populations attempt to preclude through birth control strategies (mainly late marriage); contrary to Malthus's assertion, this demographic regulation would be put to use in order to prevent labour intensification rather than to mitigate the effects of the imbalance between population and resources. These reproductive patterns result in low demographic density and a tendency toward population decline due to the decrease in birth rate, which is confirmed for the historical period of dominance of the peasant mode. ${ }^{18}$

In the peasant mode, the household produces autonomously and the product of labour remains at its disposal. This essential feature distinguishes the peasant mode from the concept of peasant economy derived from Chayanov's arguments, to which some authors have conferred the status of mode of production, ${ }^{19}$ and whose functioning is independent from the eventual subjection of peasants to relations of exploitation. It is also distinct from the peasant mode of production referred to by Kautsky and other authors, who point to a form of production that is articulated to other systems rather than to specific relations of production. ${ }^{20}$

Since producers do not have to relinquish the surplus to an exploitative class, the most important social relations in the peasant mode are those established within the household (which do not imply class-exploitation) and between the independent households. These bonds determine a specific form of property that is not subordinated to kinship relations nor mediated through the community, and whose continuity is guaranteed mainly through systems of partible inheritance. ${ }^{21}$ Given that for the most part the access to the means

17 Boserup 1993, p. 43, defines agricultural intensification as 'the gradual change towards patterns of land use which make it possible to crop a given area of land more frequently than before'.

18 Wickham 2005, pp. $551 \mathrm{ff}$.

19 According to Harrison 1977, Chayanov's theory involves social relations of production (self-exploitation of labour power), mechanisms for reproduction (the family), and a specific dynamic derived from the contradiction between consumption needs and forces of production. Kautsky 1970, p. 320. On this notion, see Banaji 2010, pp. 94-5.

21 Wickham 2005, pp. 551 ff., p. 432 (the case of Malling) and p. 324 (England). 
of production does not depend on membership in a community, the peasant mode is distinct from concepts based on kinship societies such as Meillassoux's domestic mode of production. ${ }^{22}$

Basically, the form of property in the peasant mode corresponds to that of the Germanic mode of the Formen due to the following considerations: (a) the individual household is an independent economic unit; (b) from the point of view of real appropriation of the conditions of production and its results, the direct producers are private proprietors; (c) the community does not exist as a state; (d) communal property is only a complement of individual property; (e) kinship has a secondary role; (f) exploitation is parcelled out and does not require communal labour for its valorisation; and $(\mathrm{g})$ it develops feudal relations of production. ${ }^{23}$

The forms of production and the fact that the households dispose of the product determine the characteristics of exchange, which is based on reciprocity: the productive units exchange goods in order to create or maintain social bonds and to obtain what they do not produce. ${ }^{24}$ Commercial exchange is marginal. Sahlins's criterion applies, according to which: (a) in 'primitive' societies, the households are not self-sufficient and must resort to exchange; (b) systems based on domestic production, sexual division of labour, an orientation toward consumption and product access tend toward reciprocity; and (c) transactions have an instrumental function. ${ }^{25}$

In the peasant mode, the exchange signifies cooperation, alliance and competition among households, and the quality of the exchange depends on the social distance (the closer to the household, the more disinterested or less 'economic' the exchange). ${ }^{26}$ The surplus is also consumed in collective celebrations. Generosity is a mechanism for constructing hierarchies, since it imposes a debt on the recipients and creates a social relationship which on principle is to last until the gift is returned. Differences of rank in the peasant mode derive from this operative principle by which the gift-giver has a position of power: those who give more have more recognition and subordinate others by means of the obligation to repay the gift. This takes up Marcel Mauss's criterion, according to which the act of giving more than others - the essence of potlatchis a mechanism to express superiority and legitimise or conquer a social posi-

\footnotetext{
22 Meillassoux 1991, pp. $34 \mathrm{ff}$.

23 Marx 1964, pp. 77-8o.

24 According to Sahlins 1972, ch. 5, 'generalized reciprocity' and 'balanced reciprocity', respectively.

25 Sahlins 1972, p. 83 and ch. 5 .

26 Sahlins 1972, ch. 5; Bourdieu 1990, p. 115.
} 
tion before others, ${ }^{27}$ and Bourdieu's proposition that due to social disapproval of open violence, gift-giving is the only means to assure domination in primitive societies. ${ }^{28}$ As Sahlins summarises it, 'the economic relation of giver-receiver is the political relation of leader-follower'.29

This form of distribution of the surplus defines the features of the social structure: peasant mode societies are not egalitarian because they have mechanisms to construct hierarchy. However, dependent as they are on generosity, charisma, public performance, etc., these hierarchies are not permanent, and in consequence this mode of production is correlated to unstable political forms. Inequality is also manifested by the presence of unfree individuals in the more hierarchical units.

The peasant mode implies functioning principles that work against the accumulation of wealth and power inasmuch as the construction and preservation of a position of authority depend on munificence, which leads to a constant draining of resources, and on the effective support of followers, which inhibits the deployment of oppressive practices. This problem has been formulated in different ways: the contradiction between a leader's power aspirations and his dependence on his subordinates, which is inherent to primitive leaderships, neutralises the possible development of said power (Sahlins); ${ }^{30}$ the accumulation of symbolic capital, the only recognised form of power, demands costly strategies, therefore the very maintenance of domination implies its fragility (Bourdieu); ${ }^{31}$ social competition does not involve factors of production but scarce goods that only bestow prestige if they are redistributed or destroyed in public ceremonies (Godelier). ${ }^{32}$ This dynamic leads to limited standards of wealth and preservation of the means of production and subsistence on the part of the members of the community, which in turn prevents its internal differentiation.

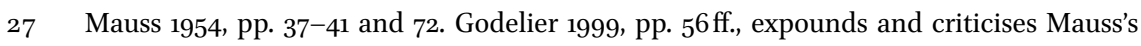
model. For the negotiation of social position through gift-exchange, see Miller 1986.

28 Bourdieu 1990, pp. 122-35.

29 Sahlins 1972, p. 133

30 Sahlins 1974, and 1972, pp. 130-48. Runciman 1989, pp. 323-5, follows Sahlins's criterion: 'The practices which define the big-man's role do indeed impose the constraint - or contradiction - that the more he accumulates, the more he must give away and therefore the more he is at risk of alienating the followers on whom his power depends if he fails to do so ... [G]iven the constraints on the practices constitutive of big-man roles, no mutation or recombination could bring about and institutional change from within'.

32 Godelier 1972, p. 289 . 
The deployment of this functioning logic assumes the absence of an aristocracy (the case of Iceland is an example) or a weak social control on the part of the aristocracy and the state over peasant populations, since the relative autonomy of the latter is the condition of possibility of such logic. Thus, the emergence of the peasant mode in the early Middle Ages is associated with a historical process of impoverishment of the aristocracy and decline of the fiscal system which took place in Western Europe between the fifth and sixth centuries.

The historical conditions for the genesis of the peasant mode in Western Europe do not imply the total dissolution of the ancient forms of property, which correspond to various modes of labour exploitation (colonate, serfdom, taxation) directly or indirectly enabled by the structures of the fiscal state. It is rather a historical process of involution of the state and retrogression in the wealth levels of the aristocrats, who lost control over their possessions and the subjugated labour force. This process took place in different manners that altered the morphology of the aristocracy, giving rise to two variations: (1) the aristocracy becomes tribalised and its power is confined to leadership over free people (and to a very limited exploitation of the unfree); or (2) it narrows its area of influence, preserving effective rights of exploitation only over a minority of the peasantry.

The first case is the 'tribal' variation of the peasant mode, in which the members of the aristocracy are mostly chieftains similar to 'big men'; in this variation, exemplified in the proto-states of Northern Europe (England, Wales, Ireland, Denmark), property has not morphed into the right to claim rent. The free men owe their local leaders or their rulers military service and a small tribute which does not affect their economic autonomy and must be repaid; this bond becomes tangible in non-permanent clientelar relations in which the followers preserve the right to withdraw or change their loyalties. In this version, the aristocracy assimilates itself to the peasant mode; that is to say, it does not constitute a separate mode of production. ${ }^{33}$

In the second case, the extraction of surplus from dependent segments denotes the presence of relations of exploitation, and thereby of another mode of production that Wickham sums up in the concept of the feudal mode, which coexists with free spaces not dominated by the aristocracy where the peasant mode manifests itself. In this case, the independent peasants are in contact

Haldon observes that Wickham dismissed the difference in meaning between the terms 'aristocracy' and 'elite'; he suggests that the latter term would have been more appropriate (Haldon 2011, p. 52). 
with feudal landowners with whom they maintain links that are more or less lax or sporadic. This is the more habitual form of existence of the peasant mode in Western Europe: integrated into a regional or micro-regional social whole in which feudal enclaves also exist. ${ }^{34}$ Wickham's image of 'leopard spots' conveys this situation of coexistence of distinct modes of production within a social formation. Both modes (feudal and peasant) articulate in different ways, giving rise to an array of situations which basically express the pre-eminence of one mode or the other in the society in question. In a social formation dominated by the peasant mode, the position of the aristocracy, whose wealth and politicial influence are limited, will depend on the support of free people, which gives rise to practices of reciprocity, such as gift-giving, in exchange for loyalty. The relationship between the aristocracy and the free peasantry follows patterns similar to those observed in societies that have undergone a process of tribalisation. Thus, the rules arising from the internal logic of the peasant mode are rendered on the whole. The dominance of the peasant mode in the early medieval social formations is evidenced in the archaeological record, which generally reflects a simplified material culture.

Both forms of existence of the peasant mode (tribal or in combination with feudal enclaves) imply the subordination of the aristocracy to the logic of the gift, which inhibits the development of accumulation processes and constrains wealth levels to its limits; this dynamic leads to a principle thwarting the transformation of societies where the peasant mode is dominant. Nevertheless, from the point of view of the form of property, the peasant mode favours the emergence of inequalities and private accumulation, which arises predictably from the individual appropriation of the fruits of labour. Marx points to this aspect in the Germanic type of property, which reflects an emancipation from kinship and community, since the community exists only as a relationship between individual proprietors; the Germanic form of individual property does not depend on membership in a collective entity, nor does the collective intervene in its valorisation; the possibility of independent economic action is the source of dissolution of egalitarianism. ${ }^{35}$ This feature of the Germanic mode has been emphasised by Alan Macfarlane with respect to the later appearance of capitalist relations. ${ }^{36}$ According to Kosminsky, the peasant social differentiation in thirteenth-century England can be explained by the previous existence of

34 Banaji 2010, p. 218, criticises this, which he refers to as 'microregionality of modes of production'.

35 Marx 1964, pp. 75 ff., pp. 142-5 (Marx to Zasulich).

$36 \quad$ Macfarlane 2002 . 
individual private property, which underlies the formation of feudalism and its evolution. ${ }^{37}$ Marx notes the undermining potential of private appropriation in his analysis of the nineteenth-century Russian agricultural commune, characterised by the predominance of divided petty cultivation; this enables private accumulation of movable goods susceptible to exchange, which stimulates internal differentiation. ${ }^{38}$ On a similar note, Engels points out that individual exploitation accounts for the increasing inequality within the Russian peasantry and leads to its disintegration, ${ }^{39}$ which was later confirmed by Lenin in his empirical analysis of the internal structure of this community. ${ }^{40}$ The peasant mode is therefore based on an individualised form of appropriation of the conditions of production which favours the development of inequality. Thus, two opposing evolutionary tendencies are combined in the historical process.

As Wickham points out, the transition mechanism is the accumulation of land and the conversion of landowning peasants into tenants, which is in accordance with the historical evolution of the Germanic mode, whose tendency toward fragmentation leads to the development of feudal relations of exploitation - and later to capitalist relations. This process, which presents differentiated traits on a microregional level, ${ }^{41}$ begins with the strengthening of the internal elites (tribal aristocracy) or the external ones (feudal aristocracy) and their distancing from the obligations of reciprocity. In the habitual form of existence of the peasant mode, whose dominance in the social formation depends on the entity of the feudal enclaves, the proximity of these enclaves exposes the independent peasant communities to seigneurial violence or the development of clientelar relations with outside aristocrats which generally involve village leaders; these bonds can lead to an enhanced social condition for those leaders, which tends to turn rank differences into class differences, or to the conversion of bonds of patronage into local relations of exploitation and domination. ${ }^{42}$ The patronage of outside aristocrats would be a mechanism for the internalisation of the values of the feudal class and a factor neutral-

37 Kosminsky 1956, p. 207: 'The deep-seated causes of peasant differentiation probably lie as far back as the disintegration of the pre-feudal lands into the ownership of separate families. The formation of allodial holdings, and the development of land alienation, were bound to result in the creation of private states'.

Marx 1964, pp. 142-5 (Marx to Zasulich). For the complete second and third drafts, see Marx 1989, pp. 360-70.

39 Engels 1989.

$40 \quad$ Lenin 1964.

41 This process varied from village to village, Wickham 2005, pp. 432-3.

42 See the case of Malling, Wickham 2005, p. $43^{2}$. 
ising class struggle. ${ }^{43}$ Here it is possible to suggest a certain parallel with Meillassoux's observations on the evolution of the domestic mode of production, which tends toward dissolution as a society of equal communities. According to Meillassoux, agricultural communites are vulnerable to external attack due to their stable location, their storage of goods, the presence of scattered producers, etc.; the need for protection leads to new organisational patterns (military alliances, etc.) which culminate in the establishment of class power; this domination, which is generally from outside the community, preserves the vocabulary of kinship or the appearance of reciprocity as an ideological underpinning for exploitation. ${ }^{44}$ For Bourdieu, this principle is already present in gift exchange, which tends to create asymmetrical bonds and engender relations of dependence that take the guise of moral obligations; as the hierarchies become institutionalised, their reproduction will rest less on symbolic forms and will be carried out through less costly and more evident means. ${ }^{45}$ In Godelier's scheme, the stabilisation of authority marks the first stage of the process by which social competition, which does not involve the access to the means of production and subsistence in primitive societies, shifts from the sphere of the distribution of products to the sphere of the distribution of factors of production. ${ }^{46}$ In our case this shift is manifested in the expansion of tenancy.

In early medieval social formations, the advance of the relations of exploitation is evidenced in the development of craft specialisation, which reflects the demand of utilitarian goods on the part of the aristocracy in keeping with its increased political hierarchy and wealth. Notwithstanding, in the regions where the feudal mode of production predominated (for example, Northern France), the peasant mode preserved a relatively independent existence. ${ }^{47}$ Considered as a whole, the process of transition to the full dominance of the feudal mode takes place in three stages:

[F]irst, a steady strengthening of aristocratic status and wealth, inside the constraints of the peasant mode and/or in neighbouring areas; second, a catastrophe-flip from a peasant to a feudal economic logic; third, the steady reduction of areas of continuing peasant autonomy inside the overall dominance of the feudal mode. ${ }^{48}$

\footnotetext{
43 Wickham 2005, p. 440.

44 Meillassoux 1991, pp. 82-8.

45 Bourdieu 1990, pp. 122-35.

46 Godelier 1974b, pp. 34-5.

47 Wickham 2005, p. 547.

$48 \quad$ Wickham 2005, p. 588.
} 
The aim of this theoretical proposition, as stated by Wickham in the first formulations of his concept, is to introduce 'more firmly' into the study of the early Middle Ages the functioning patterns that anthropologists have established for 'primitive' societies. ${ }^{49}$ Other historians before him have applied these patterns to medieval Europe, but those patterns have not been converted into a comprehensive concept aimed at the understanding of the whole, or they have not been combined with the productive structure, limiting the analysis to the sphere of circulation..$^{50}$ On the other hand, the authors in the field of anthropology who have linked elements of the 'archaic' functioning with forms of production have based their schemes on societies where the development of individual private property is rare or non-existent. ${ }^{51}$ From this perspective, the concept of peasant mode constitutes an undeniable contribution which could be considered in the framework of the analyses arising from the revision of the Formen, this time based on the property form of the Germanic mode.

It behooves us to note that this is not the author's view. In Framing the Early Middle Ages, Wickham does not mention the Germanic mode nor any other non-exploitative mode. In the author's opinion, the categorisation of non-exploitative modes is unsatisfactory; ${ }^{52}$ consequently his proposition must also be considered an attempt in this direction growing out of the efforts at systematisation of classless societies undertaken by other authors (Sahlins, Meillassoux). Wickham wants to limit the inventory of modes of production to three basic forms of labour exploitation (slave, feudal and capitalist), unifying the ones that imply a control of the productive process by the direct producers. With the same criterion (simplifying the categorisation of modes of production), he suggests the addition of only one non-exploitative mode - the peasant mode - which would reflect 'the patterns of the peasant economy that can be found when landlords or the state do not take surplus in a systematic way'.53 Given that the absence of relations of exploitation, as well as the extraction of surplus through extra-economic coercion, can be found in diverse forms of property (individual, communal), the universality of the peasant mode as

49
Wickham 1994d, p. 216.

For instance, Duby 1978, pp. 48-56, and Gurevich 1985, ch. 3. For further bibliography on the gift-exchange model and its application to early medieval societies, see Moreland 2000, p. 14, n. 62.

For instance, Meillassoux 1991, pp. 34-9; Sahlins 1972, pp. 92-4. According to Godelier 1974c, p. 87, private ownership is an exception when it comes to pre-capitalist modes of production.

Wickham 1994b, p. 45.

Wickham 2005, p. 261. 
the mode of agrarian societies without aristocratic domination presents the same difficulties as the universality of the tributary mode ('feudal' in Wickham's terminology) as the mode of pre-capitalist class societies, a perspective that several authors have criticised. ${ }^{54}$

In 'The other transition', Wickham refers to the Germanic mode ('a definable mode inside Marx's inadequately analysed congeries of non-hierarchical systems that he called the "primitive communism" mode') and dismisses its presence in the early Middle Ages based on the existence of settlements of German peasants whom he identifies with structures 'focused on some communal property'.55 Even though Marx, influenced by Maurer's work, hesitated over the features of the primitive Germanic community, his analysis underscores the individual component, which determines its potential for transformation. The degree of emancipation of the community is the criterion against which Marx compared the different forms and analysed what determines their specificity: the individual appropriation unmediated by the community is what distinguishes the Germanic mode from the ancient and the Asiatic modes; ${ }^{56}$ this distinction squares with one of the main pillars of the Formen, namely the relationship between forms of property and the dynamism of societies. ${ }^{57}$

The shift in his perspective with regard to private property in primitive Germania is found in the drafts of the letter to Vera Zasulich, where Marx mulls over a period before private property around Tacitus's time ('agricultural community') in which the individuals own the house, its surroundings and have rights of possession on the arable, a formation that would later give way to

54 Banaji 2010, pp. 183-5 and 212-14; Anderson 1979, pp. 402 ff.; Manzano Moreno 1998; Astarita 1994, and 2003. Wickham 1994a, pp. 29-30.

56 Marx states that '[i]ndividual landed property does not here appear as a contradictory form of communal landed property, nor as mediated by the community, but the other way round ... The community is neither the substance, on which the individual appears merely as the accident ... It is rather the common element in language, blood, etc., which is the premise of the individual proprietor; but on the other hand it has real being in its actual assembly for communal purposes; and, in so far as it has a separate economic existence, in the communally used hunting-grounds, pastures, etc., it is used thus by every individual proprietor as such, and not in his capacity as a representative of the state (as in Rome)' (Marx 1964, p. 80).

57 According to the Formen, "[ $\mathrm{t}$ ]he Asiatic form necessarily survives longest and most stubbornly. This is due to the fundamental principle on which it is based, that is, that the individual does not become independent of the community' (Marx 1964, p. 83). 
the private property of the arable ('new community'). ${ }^{58}$ These hesitations have affected the characterisation of primitive Germania, ${ }^{59}$ but not the type of property that Marx describes for the Formen which, in any case, following his last reflections, would be subject to a different chronology (the 'new community' would have developed at some moment between Tacitus and the migrations, and it features the free peasant still present in the Middle Ages). In conclusion, the Germanic mode of the Formen represents a specific form of property, regardless of whether it prevailed before or after Tacitus. In this respect, Dopsch has demolished the Mark theory through the philological analysis of Tacitus's Germania; ${ }^{60}$ Boutruche also supports the existence of individual private property among primitive Germans. ${ }^{61}$ Furthermore, the archaeological discovery of parcel limits confirms, for the society in question, a structure founded on private property as described in the Formen ${ }^{62}$ (regardless of the specific form of settlement).

Wickham acknowledges the vitality of 'German and non-German' free peasant communities (given their former subjection to fiscal obligations, he deems them to be derived from the ancient mode) and their return to non-exploitative systems in the early Middle Ages. ${ }^{63}$ These non-exploitative systems mostly reproduce the essence of the Germanic type, because they reproduce the allodial holding, the free heritable property. ${ }^{64}$ Therefore, the concept of the peas-

58 Marx 1964, pp. 142-5 (Marx to Zasulich); also Marx 1989; Engels 1970, pp. 293-306; see Godelier 1977, pp. 83-99.

59 Anderson 1996, p. 108, considers that reallocation of arable land was still in use in Tacitus's times; according to Seccombe 1995, pp. $5^{2-3}$, although private ownership was not unknown among the Germans, the extent of it depended on the development of agricultural techniques and agrarian practices allowing for the restoration of the soil so that it could be regularly cultivated by the same family. Boserup 1993, pp. 77-81, associates the emergence of individual property rights with agricultural intensification.

6o Dopsch 1951, pp. 58-74.

61 For a bibliography on this, see Boutruche 1959, p. 62, n. 5 .

62 García Moreno 1992.

63 Wickham 1994a, p. 30.

64 Although initially associated with family possession, according to Bonnassie, '[t]ransporté dans l'Europe du Midi par les invasions germaniques, le mot "alleu" y change totalement de sens. Il vient s'y plaquer sur la vieille notion romaine de proprietas. Il cesse donc de désigner ici le patrimoine lignager pour s' appliquer à la propriété individuelle, divisible et aliénable sans aucune sorte d'entrave' (Bonnassie 1981, p. 18). See also Bonnassie 1975, p. 205. Gurevich 1992b, p. 204ff., highlights the persistence of the original meaning of the ódal from which the word allodium would derive. This opinion is partially valid for Wickham 1994c, p. 166. 
ant mode, which I would have called the 'allodial mode of production', does not imply a new form of property. Instead, it develops aspects related to the productive forces, the social relations of exchange and the laws of social functioning. These aspects are not foreign to the society on which the elaboration of the concept of Germanic mode is based, as evidenced in Tacitus's accounts of the low intensity of labour, ${ }^{65}$ gift exchange as a form of social bonding, ${ }^{66}$ the instability of chieftains, ${ }^{67}$ and a differentiated nobility whose power over free men is limited and subordinated to the logic of the whole. ${ }^{68}$

Although Wickham does not develop the problem of property from a theoretical standpoint, he verifies the prevalence of independent landowning peasants in almost all the regions, and through his criticism of documents he demonstrates the real appropriation by free peasants of the productive resources and the product in the regions where they are referred to as tenants, as in the case of Anglo-Saxon England. Even though from the legal perspective one cannot assert the existence of peasant property in this case, the appropriation of the conditions of production and its results is not negated by the requirement of tribute, whose marginal character the author shows in his analysis of the composition of the payments owed to the rulers, which are generally informal contributions of hospitality; this is why he considers this land tenure system as 'tribal', and attributes the category of 'autonomous' rather than 'proprietors' to the free peasants who inhabit the large territorial units mentioned in Anglo Saxon charters (which maintain the lexicon of Roman law) as the exclusive property of lay or ecclesiastical entities. ${ }^{69}$ As for the communal component (whose role is secondary in the Germanic mode of the For-

65 Tacito, Germania, 14: Nec arare terram aut exspectare annum tam facile persuaseris quam vocare hostem et vulnera mereri. Pigrum quin immo et iners videtur sudore adquirere quod possis sanguine parare.

Tacito, Germania, 15: Mos est civitatibus ultro ac viritim conferre principibus vel armentorum vel frugum, quod pro honore acceptum etiam necessitatibus subvenit. Gaudent praecipue finitimarum gentium donis, quae non modo a singulis, sed et publice mittuntur; ibid., 14: [E]xigunt enim principis sui liberalitate illum bellatorem equum, illam cruentam victricemque frameam; ibid., 21: Convictibus et hospitiis non alia gens effusius indulget.

67 Tacito, Germania, 11: De minoribus rebus principes consultant; de maioribus, omnes ... Mox rex vel princeps, prout aetas cuique, prout nobilitas, prout decus bellorum, prout facundia est, audiuntur, auctoritate suadendi magis quam iubendi potestate.

68 Tacito, Germania, 7: Reges ex nobilitate, duces ex virtute sumunt. Nec regibus infinita aut libera potestas, et duces exemplo potius quam imperio, si prompti, si conspicui, si ante aciem agant, admiratione praesunt.

69 Wickham 2005, pp. 314-26. 
men), woodland, according to Wickham, 'for the most part it was accessible to anyone living in the area who wished to use it', regardless of its legal condition. ${ }^{70}$

Peasant autonomy is not attributable to a pattern of settlement. In societies of the early Middle Ages, the settlement in isolated farms proposed by Tacitus (and found in Iceland), ${ }^{71}$ which Marx followed in his Formen, coexists with the grouping in villages; in turn, peasant property appears intermixed with aristocratic patrimony. The more concentrated peoplings favour cooperation in productive activities, and such cooperation breeds concerted action on the part of the members of the community, which reaffirms their autonomy. Due to the isolation of the productive units, in the Germanic mode the community is visualised as such when the proprietors meet in an assembly. In the peasant mode, the community is defined by the social action of its members, and it is conditioned by the form of existence of aristocratic patrimony (the more scattered, the better the chances of peasant protagonism). Peasant autonomy not only means that peasants can effectively dispose of the fruits of their labour; it also means that they are capable of action independent of the aristocracy, which in turn implies an inverse relation between peasant autonomy and the development of relations of patronage with magnates from outside the community. ${ }^{72}$

Finally, by virtue of the historical conditions of its emergence, the peasant mode (except in the paradigmatic case of Iceland and generally in the protostates of Northern Europe) implies a coexistence with another mode of production, which brings the analysis to the sphere of social formation and the practices that reflect the articulation of the different modes and the subordination of ancient social forms to the dominant mode of production. With its stress on the logic of social functioning, Wickham's concept can be properly applied to the analysis of this problem.

Wickham 1994c, p. 188. The description of the communal elements of Malling is basically in accordance with the communal component of the Germanic mode of the Formen: 'Malling was not a legal entity, but it had a certain identity as a village. Villagers did not yet co-operate so much in economic tems ... but they did run livestock collectively, and also together took wood from the part of the woodland $10 \mathrm{~km}$ away that Malling had rights to ... The free men of Malling ... did however go together to the local legal assembly ... which was the meeting point of a dozen villages' (Wickham 2005, pp. 430-1). Miller 1984, p. 99, n. 14. On dispersion and localisation of farms, see Callow 2006, p. 305. 


\section{Peasant-Aristocrat Patronage Links: Transmutation of the Peasant Practice in a Feudalised Context}

In the historical dynamic of the peasant mode, the development of clientelar links is a mechanism for the construction of power that goes hand in hand with the advance of feudal relations of exploitation. We will analyse a type of clientelar relation characteristic of Castile and León during the eleventh and twelfth centuries, which is also present in Galicia and Portugal, with the aim of establishing what this bond consists of and how we can document the transition to exploitative forms. In social formations dominated by the peasant mode, the aristocracy is subordinated to the logic of reciprocity; in our case, we will start from a social formation dominated by the feudal mode a classic leopard-spot area, where the aristocracy coexists with autonomous peasants - and we will observe how this dominance subordinates surviving peasant practice by infusing it with new content. We will take up the criterion established by Meillassoux, Godelier and Bourdieu regarding the preservation of the appearance of reciprocity as a mechanism of justification or construction of relations of exploitation, and we will propose that this process undergoes intermediate stages where an ambivalence and gradual reformulation of the social practice can be observed. ${ }^{73}$

The clientelar bond we will analyse is manifested in a series of social practices: land endowment in exchange for military service, mediation and defense in judicial courts, fosterage, election of lords and hospitality. In peasant societies these practices reflect social relations based on the exchange of gifts; in the feudalised context we are analysing, however, these practices, though formally analogous, tend to place themselves at the service of the reproduction of the feudal class. The slow pace and the forms of this process conveying the expansion of feudalism are explained by the logic of the peasant mode, whose principles, even while undergoing a process of disintegration, still condition the behaviour of the aristocracy. The subordination of peasant practice happens in two stages:

(1) During the eleventh century, clientelar links in the area of Castile and León reflect an incomplete dominance of the feudal mode of production: the persons involved in these relationships (village notables, free peasants, humble knights) preserve a certain degree of autonomy and provide non-agrarian services except in the case of the servants and the unfree, with whom the aristo- 
cracy maintains ambivalent links. Clientelar relations are relatively unstable, although the ability to change loyalties tends to be reduced to a formulaic statement. Notwithstanding, this formulaic statement is used to express the client's condition as a free person or the promotion of the unfree, which indicates that non-aristocratic segments are still afforded a certain amount of protagonism; this circumstance is also manifested in the granting of lands in exchange for military support.

(2) In the early twelfth century, the process of subordination of autonomous peasants and their social forms has been accomplished: we witness the spread of collective links and the transformation of the service provided by clients into agrarian rent, as well as a crystallisation of the separation between milites and farm labourers by which the former are exempt from taxation and restrictions with regard to their political allegiance and are therefore able to join the feudal system as vassals, and the latter remain subjected to seigneurial lineages and taxation, that is to say, excluded from the category of free people from the point of view of their political capabilities and their ability to dispose of the fruits of labour. The transformation of clients into tenants is clearly visible from the early eleventh century in some pacts of the Galician-Portuguese area implying the loss of economic autonomy on the part of the clients, which reflects an earlier establishment of feudalism in that region.

The analysis of the bond between patrons and clients yields elements inherent to peasant practice that can promote this evolution. The change is also favoured by the structure of property which facilitates its transmission and disposition. This aspect has been highlighted by Reyna Pastor, who attributes seigneurial advance over village communities to the consolidation in the latter of individual property since the tenth century, within the framework of a system of property consistent with the Germanic form (combination of private and communal property, emancipation of the individual from the community); as stressed by Pierre Guichard, the disposition of individual property favours disposession and the fall into dependency, an evolution that is not observed in societies where the communal framework prevails, such as some Islamic societies. ${ }^{74}$ In this regard, Miquel Barceló has analysed the stability of clan settlements in al-Andalus, and he believes this stability to be associated with the impossibility of trading in land, which hampers the formation of a feudal class 
through absorption of patrimony. ${ }^{75}$ Thus, this latter phenomenon encounters more favourable conditions in places with a predominance of communities emancipated from kinship.

What follows is an analysis of the transformation of clientelar bonds and their structural foundations stemming from the social functioning of the peasant mode. We will examine how the opposing evolutionary tendencies typical of this system combine (peasant dispossession/limitation of accumulation).

\section{Gifts of Lands to Peasants}

One of the features of the bond between patron and client is the granting of lands in exchange for services. Land endowments on the part of the patron abound in the eleventh-century records. They are charters of donation or sale which refer to the recipient's ability to choose a lord. ${ }^{76}$ In almost every case, members of comital families cede land in order to obtain, maintain or repay a service, mainly military service, as can be deduced from the fact that the clients give or promise to give swords and horses in exchange for the gift. ${ }^{77}$ The meaning of the phrase bene facere as a synonym of land endowment for military service can be traced to tenth-century laws which exempt from military service those knights who have not been granted material means of support, ordering them to seek a lord that will grant them. ${ }^{78}$

The endowments can be temporary, for life or hereditary. They are more likely loans of land subject to the duration of the bond. Notwithstanding, in some documents the ceded lands are equated with allodial holdings, which on principle is consistent with the form of property of the peasant mode: the recipients can donate the land, sell it, bequeath it, etc. ${ }^{79}$ The grants include

75 Barceló 1990, pp. 105 ff. Guichard 1984, p. 131, has observed the existence of collective forms of appropriation and North African kinship structures that hamper land transfers in al-Andalus.

76 Ut vadas ad qualem dominum volueris, pergas cum ipso solare ad qualemcumque dominum volueris, qui tibi bene fecerit, etc. Herrero de la Fuente 1988a, and 1988b; Fernández Flórez 1991; Ruiz Asencio 1987, and 1990. For instance, Herrero de la Fuente 1988b, doc. 826 (1086): Ego Beliti Citiz a uobis Martino Flayniz, domino meo, dauo uobis una espata ualente $x x$ solidos de argento.

78 Muñoz y Romero 1847, p. 38, Fuero de Castrojeriz (974): Caballero de castro, qui non tenuerit prestamo, non vadat in fonsado, nisi dederint ei espensam, et sarcano illo Merino et habeant segniorem, qui benefecerit illos.

79 Herrero de la Fuente 1988a, doc. 566 (1054): Aveas, vindeas, dones, commutes tu et filiis tuis quo tivi queris; doc. 702 (1071): abeasque licentiam facendi ex eo quod tua extiterit uoluntas; Fernández Flórez 1991, doc. $125^{2}$ (1133): et faciatis ex eo quicquid extiterit uestra 
the right to communal land as an accessory of the individual plot, precisely as found in the Germanic form. ${ }^{80} \mathrm{~A}$ couple of cases note the client's prior condition as private proprietor: one of the recipients has previously sold some pieces of land acquired through purchase which are free and clear of any obligation. ${ }^{81}$ Another case confirms the sale of lands that had been acquired as payment for non-agrarian service. ${ }^{82}$

It has been suggested that the terminology related to full ownership ( faciatis ex eo quicquid exiterit uestra uoluntas, etc.) could reflect the constitution of a bond, which even if disposition of the property is possible, implies an obligation for the recipient. ${ }^{83}$ As William Ian Miller observes in his study of family sagas, gifts of lands were avoided or feared in view of the implied relation of subordination to the giver derived from the fact that the debt could only be settled with another grant of lands. ${ }^{84}$ The spread of this practice in eleventhcentury Castile and León reflects the construction of power by means of gifts that can only be repaid with services, as well as the denaturation of allodial holdings, which tend to become tenancies subject to rent or conditioned property; the preservation of the lexicon of full ownership could result from the need to acknowledge the free condition of the land recipients, whom the law equates to (but does not confuse with) the aristocracy. ${ }^{85}$

In fact these procedures emulate the transactions between members of the aristocracy in which the gifts of lands are reciprocated with symbolic presents: the patrons receive horses, greyhounds, swords or mules from their clients as

uoluntas, uendere, donare; et habeatis ipsum solare confirmatum, uos et omnis posteritas uestra; doc. 1189 (1113): et quicquid tibi de illa placuerit facere, facias: uendere, dare, tua uoluntate complere, in uita siue post mortem, tu et ex omni progenie tua.

8o Herrero de la Fuente 1988a, doc. 634 (1063): Facium tiui kartula de uno solare cum sua erea et cum suo orto et cum suo exitum ab intro et at foras.

$81 \quad$ Herrero de la Fuente 1988a, doc. 624 (1063) and doc. 578 (1056): Ut uinderem uobis ego Gundisaluo presbiter et germana mea Geluira una corte de mea comparacione ... ut de isto die de iuri nostro abstracto uestro sit tradito et faciatis de eo quod uestra extiterit uoluntas.

82 Herrero de la Fuente 1988b, doc. 1086 (1102): Et habui ego Citi Albariz ipso solare de incartacione de comite Pedro Ansuriz et de sua mulier, propter filios eorum que ego nutriui ... Facio tibi carta per tale foro quomodo ille comes michi fecit et vadas cum eo ubi volueris, tu et filius tuus et omnis progenie tua.

83 Morsel 2008, p. 207.

84 Miller 1986, pp. $49 \mathrm{ff}$.

85 Pérez Prendez y Muñoz de Arraco 1988, Fuero de León (o), tit. x: Praecipimus etiam ut nullus nobilis sive aliquis de benefactoria emat solare aut ortum alicuius junioris. 
counter-gifts. ${ }^{86}$ The transfer of horses in exchange for protection and means of subsistence shows up in Laxdcela saga; Miller highlights the subordination of the economic content of the transaction, which is presented as a sale, to the social relationship established between the parties which precludes the disassociation of the goods from their bearers; he who acquires horses also acquires obligations toward their prior owner and his family, to whom he cedes lands. ${ }^{87}$ In our case the clients probably did not part from the objects they offered as a symbolic closing of the transaction, since they used them to serve their patron and the objects symbolised that service. Their condition as knights was precarious: in a will dated between 1085 and 1115, the patron awards his client some land and the horse the latter was using, which shows that many knights did not own their horses, and that clients were provided with the equipment for military service. ${ }^{88}$ In a covenant of 1073 , the client is given land and a colt; $; 9$ in another case, along with the land, the client receives a horse, a mule, three oxen, 22 sheep and seven pigs. ${ }^{90}$ These goods are described as components of the productive unit, which permits an estimation of the amount of means of production at stake, equivalent to a domestic unit of modest proportions. It follows from this that our client is a peasant who is being granted basic means of subsistence and the essentials of military equipment with which he will be able to lend his support to various members of the aristocracy. ${ }^{91}$

The need to secure loyalties among the peasantry shows that the development of feudalism was incomplete in the area. Competition among lords is evidenced in material endowments aimed at gaining supporters. In 1063, Juliana Muñiz grants lands to Sesgudo Escámez in the locality of Santa Cruz; Sesgudo reciprocates with a horse. ${ }^{92}$ The following year, Juliana rewards Sesgudo once more for his good service with a plot of land in another location, ${ }^{93}$

86 Herrero de la Fuente 1988a, doc. 634 (1063), 638 (1064), 702 (1071), 713 (1072), 719 (1073), 720 (1073); Herrero de la Fuente 1988b, doc. 826 (1086), 887 (1092), 795 (1081); Fernández Flórez 1991, doc. 1198 (1117).

$87 \quad$ Miller 1986, p. 48; Laxdcela saga, ch. 36.

88 Herrero de la Fuente 1988b, doc. 1173 (1085-1115): Et tibi, Martino Munniz, dono uno solare, ubi tu volueris; et illum cauallum quem tenes de me, habeas solutum pro mea anima; pergasque cum ipso solare ad qualemcumque dominum uolueris.

89 Herrero de la Fuente 1988a, doc. 721 (1073).

$90 \quad$ Ruiz Asencio 1990, doc. 1233 (1084).

91 Ruiz Asencio 1990, doc. 1233 (1084): cum tale foro de mare ad mare, ad rei, ad conde, ad infancone, ad quale dono uoleris in ipso solare sedente medio die et media ora.

92 Herrero de la Fuente 1988a, doc. 634 (1063).

93 Herrero de la Fuente 1988a, doc. 683 (1064). 
which shows that Sesgudo's loyalty had to be renewed, and that land grants did not guarantee the sustained support of the clients. As for the clients, in some cases they appear as serving different patrons simultaneously: for example, in 1073 Rodrigo Miguélez is awarded lands belonging to Armentario Vélez; in exchange he offers a grey horse; ${ }^{94}$ during the same year he receives another piece of land in the same village from Pedro Vermúdez and in full ownership, this time in exchange for a roan horse and a greyhound. ${ }^{95}$ The dimensions of these properties (the amount that can be tilled with two oxen) correspond to a family holding, ${ }^{96}$ which places our client among the peasantry of the village. At this level we witness competition in order to recruit supporters through gifts of lands, which must be equivalent to those of other lords in the same location; such is the case of Elvira, who in 1071 grants a client a piece of land in Santa Cruz 'of the same size as that of Sesgudo' (who had received lands from Juliana Muñiz). ${ }^{97}$ The example also illustrates the coexistence of a variety of bonds within the same village, which in turn reflects peasant protagonism.

The individuals who take part in these relationships could resemble the milites of peasant origin detected by Bonnassie in eleventh-century Catalonia, less submissive villagers who served various lords at the same time without taking on relevant obligations with any of them and without becoming fully integrated into the system of feudal vassalage: the author distinguishes them from the milites castri committed to the defence of fortresses who would end up incorporated into the ranks of the aristocracy. ${ }^{98}$ Historians have recognised the material endowments for a client's military service as a precedent of beneficial concessions ${ }^{99}$ and they have also observed the direct transformation of clientelar bonds into feudo-vassalic relationships, ${ }^{100}$ the incorporation of rural segments to the seigneurial armed retinue has been related to the reorganisation and adaptation of the aristocracy to the structural requirements of banal lordship. ${ }^{101}$ In some cases, the relationship of benefactoria could be inscribed

\footnotetext{
94 Herrero de la Fuente 1988a, doc. 719 (1073).

95 Herrero de la Fuente 1988a, doc. 720 (1073): Ut de isto die habeas licenciam faciendi de ipso solare et de ipsa hereditate quod tua extiterit uoluntas.

96 Herrero de la Fuente 1988a, doc. 720 (1073): cum suas terras, ut habeat uno iugo de boves ad duas folias in aratura quod laborent.

97 Herrero de la Fuente 1988a, doc. 702 (1071): Ut uinderemus tibi Steuano Ciluanez uno solare similiter tamanio quomodo est ille de Sesguto Examiz.

98 Bonnassie 1975, II, pp. $800 \mathrm{ff}$.

99 Dopsch 1951, pp. 386 ff.; White 2003, p. 98.

$100 \quad$ Morsel 2008, p. 68.

101 Morsel 2008, pp. 149-50.
} 
in this process of reformulation and expansion of the aristocracy involving the transformation of clients into vassals, which illustrates one of the avenues for the disintegration of peasant societies through the social promotion of their leaders; on the other hand, we will observe that the relatively undifferentiated group of clients tends to become split into milites and farm labourers over the course of the century; the former will likely become integrated into féodalité, whereas the latter become subject to feudal relations of exploitation.

\section{Conflict Mediation and the Performance of Patrons in the Assembly}

Patrons acted as conflict mediators and advocates for their clients in courts. These functions have been well documented in Galicia and Portugal. Let us review an example. In 1008, two siblings, Adosinda and Argerigo, sell a piece of land to the local priest in exchange for livestock and food. The reason for the transaction is that the priest has helped them by acting as mediator before Adosinda's husband, whom she has betrayed, and perhaps he also acted on their behalf before the higher authority to whom a fine for adultery is due, which the siblings apparently have only partially paid. The priest intercedes with Adosinda's husband on her behalf, he gathers representatives from both families in his own house, he counsels them and manages to reconcile the parties. This performance is the essence of the covenant of 'bemfeitoria' ${ }^{102}$

Conflict resolution is the main manifestation of functional power in peasant mode societies. ${ }^{103}$ Success in lawsuits depends to a large extent on the support marshalled for one cause, that is to say, on the number of men the leader can bring to the assembly in support of his suit, which is in direct relation with his reputation as a successful jurist. The role of local leaders as advocates, mediators and peacemakers has been highlighted by scholars of the Icelandic sagas. ${ }^{104}$ The mediator's mission is to reconcile the parties in a manner that is

102 Portugaliae Monumenta Historica. Diplomata et chartae, CCII (1008), p. 124: Quanto inde tenemus in nostro iure qum mater nostra goda ... nos tivi inde rovoramus medietate integra ... Et dedisti nobis adduc in pretio II boves et III modios de zivario et II as cabras et uno carnario tanto nobis bene complacuit ... Et damus tibi ea pro occasione que abenit ad ipsa adosinda et in suo peccato devenit a tradictione et abuit pro me a dare $c L$ solidos et dedit inde illos $L$ ad uilifonso mumdinizi ... Et favolastis pro me ad meo marito virterla et dimisit mici illa merze et rezebit me pro sua muliere et consudunasti nos todos tres in tua kasa ad tua bemfeitoria.

103 Wickham 2005, pp. 431-2, the advocacy for neighbours in court is the main role of Eahlmund and Ælfwine, Malling leaders. The reconstruction of Malling is based on the case of medieval Iceland.

104 Miller 1990, pp. 259-99, and 1984; Byock 2001, pp. 66 ff. 
either complementary or an alternative to the judicial resolution of the case. As Bourdieu remarks, representation in courts and conflict mediation are typical forms of accumulation of symbolic capital. ${ }^{105}$

An episode of Eyrbyggja saga highlights one aspect of the intervention of third parties in disputes between households: land grants as repayment for representation services in courts. In this case the litigants do not wish to reconcile, but to win the case in the assembly. ${ }^{106}$ Thorolf and Ulfar are feuding neighbours. Thorolf's son Arnkel, who is a renowned goði, always tries to compensate Ulfar for his father's hostile actions. Thorolf dispatches slaves to set fire to Ulfar's house; Arnkel seeks them out and kills them. Ulfar transfers his property to Arnkel (who favours his leadership over his kinship) in exchange for his protection. Thorolf demands compensation for his dead slaves; Arnkel refuses to pay it; Thorolf decides to bring his case to the courts, which requires that he find a specialist as renowned as Arnkel or even more so. Since Arnkel is one of the goðar of the district, Thorolf should appeal to Arnkel, but Thorolf makes use of his liberties to change allegiance and appeals to Snorri goði for him to present the case before the assembly. At first Snorri refuses, because the case is unpopular, but Thorolf secures his support by offering him lands. Thorolf transfers the lands but retains the usufruct; upon his death they will become Snorri's outright property. ${ }^{107}$ There is rivalry between Snorri and Arnkel; Snorri has taken advantage of the opportunity to see Arnkel disinherited. Thorolf's interest in the matter, as Miller suggests, is not material, since the value of the land exceeds the compensation he could obtain for the slaves; by winning the case in the assembly, which is what he expects to do by means of Snorri's abilities, Thorolf enhances his reputation and reconstructs alliances predicated from his bond with a renowned chieftain. The gift of lands has served him to disinherit his son, from whom he is estranged, to intervene in a dispute between two chieftains competing to gain supporters, and to consolidate his own status through the success of his case in the assembly.

This example could illuminate some aspects of the clientelar relationship that concern us. In the adultery case reviewed above, the gift of land to the priest who brokered the reconciliation between both families does not appear disproportionate if one considers that the woman who cedes the land could

105 Bourdieu 1990, pp. 128-9.

106 Eyrbyggja saga, ch. 31. This episode has been analysed by Miller 1984, pp. 126-32, and 1990, pp. 289-94; Byock 1982, pp. 152-4, and 2001, pp. 99-117.

107 On the transfer of land in medieval Iceland, see Miller 1984, p. 126, n. 123, and 1986, p. 47, n. 106 . 
have been rejected by her husband and lost all chances of remarrying, which would have put her family, represented by her brother, in a grave predicament. In these circumstances, the siblings' bond with a prominent local character such as the priest is for them more valuable than the land, since it implies a certain position within the community and avoids a conflict between families. Just as in Eyrbyggja saga, the granting of lands - which is reciprocated with livestock and food - builds a social relationship which does not imply economic exploitation (there is no mention of tributes) but a political alliance between free people, even when the transaction contributes to the accrual of patrimony for one of the parties involved. It follows that this latter phenomenon, which in a general sense accompanies the expansion of feudal relations of exploitation, is rooted in precedents reflecting the social functioning of the peasant mode (the granting of land in return for mediation services), and whose condition of possibility is a property structure that objectively favours these transactions (the existence of individual private property). Byock characterises the property structure in Iceland as 'a system of allodial-type landownership' which protects the rights of the heirs, although the alienation of the property is eventually subject to the wishes or the weakness of the proprietors. Drawing from the episode of Eyrbyggja saga (mainly the transfer of lands from Ulfar to Arnkel) and other examples, Byock suggests that the intervention in conflicts is a tactic for the acquisition of land on the part of the chieftains, and that they resort to it depending on the balance of power they envision having if familial claims eventually arise. ${ }^{108}$ The author offers examples in which thingmenn in trouble transfer lands to their chieftains in order to obtain protection or representation in court. ${ }^{109}$ Thus, the potential for dissolution derived from the property form of the peasant mode is expressed in social practices rooted in status disputes, which in turn may suggest the existence of principles of change inherent to the logic of how peasant societies work.

The evolution of this tendency can be observed in some benefactoria covenants arising from the need of mediation or representation which lead to the loss of economic autonomy for the clients. These are agreements struck after a crime has been commmitted, which summon the patrons to one of the typical functions of political leaders in peasant mode societies: to help in court cases in which their clients are involved. (This phenomenon could derive from the relative prevalence of a primitive conception of honour, which explains the

\footnotetext{
108 Byock 1982, pp. $148 \mathrm{ff}$.

109 Byock 2001, pp. 275-81. Payments to chieftains during the support-gathering process were common practice; see Miller 1990, p. 242; also Njal's saga, ch. 49, 134, 138.
} 
frequency of homicide among peasants and the resulting need for support in courts of law. ${ }^{110}$ In 1022, Gontoi and his wife cede half of their property to an individual linked to the monastery of Celanova in exchange for his help in a situation involving one of the couple's sons, who has committed adultery. Gontoi and his wife want to avoid the consequences of a lawsuit, and if things were to reach that instance, they want support in court; the document highlights this function of the patron: abeamus de vobis defensionem et moderationem et in verbo et in facto et in concilio et in benefactoria. ${ }^{111}$

The ability to convince and persuade with words, which is put to the test in the assembly, distinguishes the leaders in peasant societies and is one of the foundations of their authority. This attribute is associated with the figure of the patron in the cases quoted and originally it may have constituted one of the determining factors for the election of the lord. In the case of the priest who intervenes in a dispute between families, the capacity for persuasion is key to his performance (et favolastis pro me); in the other case, instead, the allusion to rhetorical abilities and performance in the assembly (defensionem in verbo ... et in concilio) seems to be a formulaic statement attached to the mention of the patron rather than an indication of his specific qualities, which reflects the subordination of the social practice to other contents, or their formal preservation, a prerequisite of their mutation; by acting as mediator (abeamus de vobis moderationem) the patron obtains the right to the appropriation of surpluses. ${ }^{112}$

In another case dating to 1012, a certain Daildo is accused of abduction by the king's local agents, count Rodrigo Ordóñez and the father of the victim. ${ }^{113}$ Aloiti, the former abbot of Celanova, who has since been transferred to another monastery, shows up at the venue to pay the fine for abduction, perhaps because he had acted as Daildo's patron in prior occasions; in repayment, Daildo offers him two pieces of land, only one of which really belongs to him; the ruse is uncovered and Daildo is accused of calumny and ordered to cede two more pieces of land in replacement of the false one. After the intervention of some men (who, strictly speaking, fulfil the function of mediation), Aloiti takes pity on the man and forgives him with theatrical flair, which means

\footnotetext{
110 On the persistence of the feud culture, see Hyams 2001.

111 Andrade Cernadas 1995, doc. 547 (1022).

112 Andrade Cernadas 1995, doc. 547 (1022): Et demus vobis per annis singulis ad area et at lagare medietate tam de pane et bibere quam etiam et de omnes fruges quod Dominus in ipsa villa dedit, medium vobis demus et medium remaneat pro nobis.

113 Andrade Cernadas 1995, doc. 572 (1012).
} 
Daildo ends up losing two properties instead of three. ${ }^{114}$ The speech of the one who chairs the assembly, addressed to Aloiti the patron, demonstrates that in this case conflict mediation is perceived as an instrument of social disciplining: Venistis ad ipsum monasterium ad corregendum, ad salvandum, ad moderandum, ad benefaciendum ad oves Dei que iam disperse erant. Daildo will carry on cultivating both pieces of land and will give one third of the product to the monastery of Celanova. ${ }^{115}$

In contrast to the first case (the one of the local priest who manages to reconcile two families), in the two latter cases the assignees remain committed to rent payments, which indicates that the clientelar relationship no longer expresses an alliance between free people but the slip into dependency of one of the parties. Furthermore, while in the first case the patron mediated in a conflict between families, in the two latter ones the mediation is aimed at mitigating the effects of the administration of justice on the accused, which go beyond the settlement of the issue with a fine. This motivation, which arises when justice becomes a source of income and an instrument of subordination, ${ }^{116}$ contributes to the spread of the practice of ceding lands to the mediators. This tendency illustrates the degradation of the peasant practice in a feudalised context: the gift of lands to compensate the service of prominent jurists, a tool for status negotiation in peasant societies, becomes in the new framework a regular mechanism for the absorption of property and the expansion of feudal relations of exploitation albeit preserving the appearance of the primitive practice, according to which the patrons are presented as capable figures able to successfully steer a cause in the assembly or negotiate an agreement.

The development of relations of exploitation in the area is also manifested in the dispute between fractions of the dominant class over those who have not yet been incorporated into the feudal system: the patrons attempt to protect their free clients from the seigneurial advance of rival powers. In

114 Andrade Cernadas 1995, doc. 572 (1012): Et dum talia vidimus et aures audivimus et non habuimus unde omnia ipsa villa componere per lege, fabulauimus ad homines idoneos qui fabularunt vobis ad misericordia et pro vestra mercede vidistis et intellexistis lacrimis et suspiriis vestris et posuistis aurem ad audiendum, et cor ad intelligendum et dimistis nobis ipsam calumniam de ipsam villam quod abebamus ad duplare.

115 Andrade Cernadas 1995, doc. 572 (1012): ut demus vobis pannis singulis ad area et at lagare tercia integra, tam de pane quam de bibere.

116 Andrade Cernadas 1995, doc. 572 (1012): et eiecistis nos de illorum manuum et de sua ligamine. On landownership formation through the exercise of justice see Sánchez Albornoz 1978, ch. 2, and Astarita 2007b, pp. $116 \mathrm{ff}$. 
the following example we will examine the patron's actions in the assembly and outside of it as a result of a crime committed by one of his clients. The case is a homicide involving a client of count Sancho and the monastery of Celanova. ${ }^{117}$ Tedón, a maullatus of count Sancho, has killed a man from the monastery of Celanova with his lance, for which he is chained and jailed. His wife offers a piece of land as bail and manages to have Tedón's chains removed until his situation is resolved. Once free, Tedón begins to whip up support: he turns to his patron, count Sancho, and tells him his own version of the events, according to which he has been wrongly accused. Infuriated by Tedon's account, the count sends a man to demand an explanation from the abbot; 118 the abbot maintains that Tedón is guilty and the envoy maintains his innocence, so the case is brought to the assembly, where the count, who chairs it, argues with the men of the monastery of Celanova and attempts to defend his client. ${ }^{119}$ As a last recourse, the count decides to submit the case to arbitration, so that he can be exonerated; five persons give testimony, after which they proceed to the ordeal of hot water. This turns out a result favourable to the monastery of Celanova, which suggests that Tedón did not have the support of his own community. ${ }^{120}$ Tedón and his wife leave the assembly in anguish, perhaps because they expected a different outcome as the count was their ally; in compensation for the homicide they have to cede one piece of land. ${ }^{121}$

The example illustrates the context surrounding the action of mediators, where the administration of justice is a mechanism for the accumulation of patrimony on the part of the accusers, which in this case is not in step with

117 Andrade Cernadas 1995, pp. 656-8, doc. 474 (1056). Sánchez Albornoz 1976a, pp. 89-90, has referred to this document, which in his opinion shows patron obligations in a relation of benefactoria.

118 Andrade Cernadas 1995, doc. 474 (1056): Ille comite talia audiente causa non fuit illiplacibile, sed exarsit nimis in forore et ira pro suo mallato, que absque veritate iudicaverant et tanta mala sustinuerat. Tunc suscitavit homine bono nomine Sandino ... et direxit ad ille abba pro qua causa talia egisset.

119 Andrade Cernadas 1995, doc. 474 (1056): baraliaverunt de ista actio non modica sed multa causa.

120 For this understanding of the trial by ordeal, see Moore 1987, ch. 4.

121 Andrade Cernadas 1995, doc. 474 (1056): Illos vero non habuerunt unde ista omnia adimplere, sed molestia detemti tulerunt se de concilio. At ubi iudex vidit talia prosequentes et ad concilio nullatenus venientes mandavit suo saione ut adsignasset ad ille abba et ad suos fratres hereditate de Mortaria sicut et fecit. Et teneant ea usque reddat ipse Tetone et sua mulier ipso omicidio sicut veritas docet. The land cession to the monastery of Celanova in doc. 475 . 
the patron's sectoral interest. Quite to the contrary, the count does not wish his client, a free proprietor, to become subjected to a feudal contender, which is why he defends him before the assembly, recreating the political performance of primitive chieftains. Even though the count's intervention does not solve Tedon's predicament in view of the fact that Tedón has to cede a piece of land to the monastery of Celanova, the clientelar bond preserves the forms of peasant practice. The context, however, alters its essential content, since it shifts the patron's action from the sphere of status negotiation to the sphere of competition between fractions of the feudal class and puts at stake the economic autonomy of the client, who loses his condition of proprietor.

In one of the charters of Sahagún, the administration of justice in the locality is a requisite for being elected lord, ${ }^{122}$ which indicates that the patron's intervention in his clients' disputes is still a typical practice, however much that practice, as we have observed in other areas, is now oriented to the absorption of properties or the defence of the clientelar base when the one absorbing the properties is a rival power. In turn, the obligation to accompany the patron to the assembly (one of the contents of the goðar-bœendr relationship) may have been a part of the service that clients had to render. This was an obligation for milites living in land that was not their own, who had to attend the assembly that the landowner attended. ${ }^{123}$ There is some evidence of client attendance to assemblies: they show up as witnesses a short time after committing to a patron. ${ }^{124}$ These sources point to the fact that the clients, whom we have identified as peasants, have not yet been totally removed from public courts, which confirms the dual character of the society in question.

122 Herrero de la Fuente 1988a, doc. 549 (1051): uadat cum illo a quibus voluerit de heredes mei qui in ipsam villam iussionem habuerint.

123 Pérez Prendes y Muñoz de Arraco 1988, Fuero de León (o), xxvi: Si vero miles in Legione in solo alterius casam habuerit, bis in anno eat cum domino soli ad iunctam ... et habeat dominum qualemcumque voluerit.

124 Herrero de la Fuente 1988a, doc. 549, 635; Herrero de la Fuente 1988b, doc. 826, 836, $887,985,818,851,1015$ and 1031. Citi Pérez appears as a client in 1051 (doc. 549) and as a confirmer in 1063 (doc. 635); Velite Cítiz receives lands in 1086 (doc. 826) and appears in the witness-list one year later (doc. 836); Vela Velázquez acts as a confirmer (doc. 887) three years after receiving lands (doc. 985); Pedro Iústiz accepts lands in 1085 (doc. 818) and appears as a confirmer four years later (doc. 851); after litigation with the abbey, Pedro Cítiz agrees in court his condition of homine de benefactoria (doc. 1015); he appears as a confirmer the year after (doc. 1031). 


\section{Fosterage}

In many cases, the covenants of benefactoria formalise fosterage bonds. They involve mostly clients bringing up the children of their patrons, a service for which the patron grants them lands, but we can also attest to bonds in the inverse direction; it can be stated broadly that both clients and patrons acted as fosterers. ${ }^{125}$

The Icelandic sagas offer numerous examples of the fosterage bond, which often seals agreements between families, matrimonial alliances or proposals for reconciliation. Hoskuld, one of the central characters of Njal's saga, has been brought up by Njal after his father Thrain was murdered by Skarp-Hedin, Njal's son (we will later address the motives of this murder). ${ }^{26}$ After paying compensation for Thrain's death, Njal gifts Hoskuld with a ring and offers to take him home. Njal, a prominent Icelandic jurist, takes care of Hoskuld's education until he becomes a goð $i$. In this case, the practice of fosterage complements the wergeld and consolidates the reconciliation of the families.

The fosterage bond, as opposed to adoption or profiliatio, does not imply heredity rights for the foster-children, although they are frequently endowed with lands; Njal buys lands for Hoskuld to settle in when he gets married. Notwithstanding, although foster-children do not enjoy the same privileges as biological children, they share with them the commitment to uphold the honour of the family that has raised them, which generally implies committing to blood vengeance. ${ }^{127}$ In Hoskuld's case, the opportunity to act to redress his foster family's dishonour presents itself with the murder of Njal's natural son. Skarp-Hedin cannot conceive of a solution other than direct vengeance and he murders two of the participants, but a third one who manages to escape sues for reconciliation and obtains it through the intermediation of Hoskuld, who is by now the most renowned go ${ }_{i}$ in the district. Skarp-Hedin will never forgive Hoskuld for having interceded in favour of an enemy of the family: this bad blood is behind the events that some time later lead to Skarp-Hedin's murder of the peaceful Hoskuld. Even though Hoskuld's death, unlike other deaths, is presented in the saga as a tragic event, it still reflects the social functioning: Hoskuld has failed to fulfil his duty toward the family that raised him.

Njal's saga also provides examples of members of high-ranking families being fostered by servants. Skarp-Hedin has been brought up by Thord, the son

125 Multi eorum erant nutricii et alumpni militum ... et nutriebant filios et filias eorum, cited by Alfonso 2002, p. 250.

126 Njal's saga, ch. 94.

127 Rose 1926. For references on fosterage in a variety of primitive societies, see Parkes 2003, pp. 741-82. 
of a freedman. Thord becomes involved in one of Skarp-Hedin's disputes. When Thord's assassins (accompanied by Thrain, Hoskuld's father, who observes the scene) ambush him, they allude to the warlike qualities that Thord has passed on to Skarp-Hedin. Thord replies that those qualities will be put to the test because Skarp-Hedin will repay the gift he received by avenging the death of his foster-father. ${ }^{128}$ In the dialogue between Thord and his assassins lies implicit the substance of gift-exchange according to Mauss, for whom the spiritual force attributed to the gift drives its return to the giver. ${ }^{129}$ This is also implied in Hoskuld's acceptance of the ring and Njal's protection as gestures of the same nature; Hoskuld does not properly return the gift he accepted and therein lies the cause of his death. In the case of Skarp-Hedin and his foster-father Thord, even though Thord is a servant, his death causes Skarp-Hedin to become personally implicated, and despite having obtained compensation he fulfils the blood vengeance by slaying all the participants (including Thrain, whom he murders twenty years later); ${ }^{130}$ thus, Skarp-Hedin upholds the rules of his society. The importance of Thord's death in the saga's narrative structure is a testimony to the hierarchy of the fosterage bond in peasant mode societies.

From the perspective of social competition, a principle of social imbalance is implicit in the circulation of individuals among households. ${ }^{131}$ The fosterage bond of non-related persons is considered as a form of clientelar alliance between families of different rank, and a key political tool in the struggle between rival factions and clans. ${ }^{132}$ In medieval Ireland, the delivery of children to subordinates is complemented with gifts of lands, in exchange for which the givers obtain the clients' political allegiance, military services and hospitality. ${ }^{133}$

128 Njal's saga, ch. 42:

Sigmund said to him, 'Give yourself up, for now it is time for you to die'.

'Certainly not', said Thord. 'Come and fight me in single combat'.

'Certainly not', said Sigmund. 'We shall make use of our advantage in numbers. It's not surprising that Skarp-Hedin is so formidable, since the saying goes that one-fourth comes from the foster-father'.

'You shall see the full force of that', said Thord, 'for Skarp-Hedin will avenge me'.

129 Mauss 1954, pp. 61-2. For criticisms, see Godelier 1999; Sahlins 1972, ch. 4; Wagner-Hasel 2003, among others. Mauss's explanation is valid for Gurevich 1985, ch. 2; see also Gurevich $1992 \mathrm{a}$.

$130 \quad$ Njal's saga, ch. 92.

131 Miller 1990, pp. 122-4 and 171-4; Gurevich 1992a, pp. 187-8.

132 Parkes 2003, pp. $753 \mathrm{ff}$.

133 Parkes 2006, pp. 363 . 
The upbringing of the children of patrons is a characteristic practice of the benefactoria relationship. In 1102 an individual sells a piece of land he had obtained from count Pedro Ansúrez in compensation for having fostered his children. ${ }^{134}$ Some authors have suggested that in this example the fosterage bond can be understood within the frame of vassalage, which would include the military instruction of the lord's children by his vassals. ${ }^{135}$ However, as we shall explain, these are differentiated bonds involving distinct social segments.

In 1064, countess Mumadonna cedes lands to Velite Álvarez, a family servant, so that he may cultivate them. ${ }^{136}$ Velite reciprocates the gift with a horse, a greyhound and a hound, suggesting that despite being a servant he holds a special position, which could be explained by the fact that he has fostered Mumadonna's son, count Pedro Muñoz. Four years later the count initiates proceedings to endow Velite with lands: he requests lands from Alfonso VI, a fact that could suggest a relative patrimonial weakness of the comital aristocracy while also demonstrating the importance they attributed to clientelar bonds, which comprised land donations for their servants. Alfonso vi gives the count, whom he calls fideli meo, the lands he had requested for Velite, amo tuo in the words of the king. ${ }^{137}$ This indicates that the count has used his bond of vassalage with the king in order to build a relationship of benefactoria with his fosterfather. Once the land is transferred to the count, he in turn grants it to Velite, who will be free to choose his lord. In both transactions, the one who receives the land (first the count and then Velite) repays the donation with horses, which places servants and aristocrats in the same plane. Finally, should Velite die without heirs the land will pass on to the monastery of Sahagún for the salvation of his soul, that of his patron and the king's, since the latter provided the land. ${ }^{138}$ The bond of vassalage between the count and the king is not confused with the fosterage relationship; at most it could be argued that it conditions the relationship between the count and his foster-father: it allows the former to

134 Herrero de la Fuente 1988b, doc. 1086 (1102): Et habui ego Citi Albariz ipso solare de incartacione de comite Pedro Ansuriz et de sua mulier, propter filios eorum que ego nutriui ... Facio tibi carta per tale foro quomodo ille comes michi fecit et vadas cum eo ubi volueris, tu et filius tuus et omnis progenie tua.

135 Barton 1997, p. 47. Also Morsel 2008, pp. 83-4, suggests that fosterage was an aristocratic practice aimed at the consolidation of friendly relationships.

${ }_{13} 6$ Herrero de la Fuente 1988a, doc. 638 (1064): tibi criado nostro ... Et damus cum eos foro ... et ares quantum potueris.

137 Herrero de la Fuente 1988a, doc. 675 (1068): Do tibi ista corte quam michi petisti pro ad amo tuo Velliti Albaret.

138 Herrero de la Fuente 1988a, doc. 675 and 676 (1068). 
endow with lands and it imposes on the latter the obligation to transfer it post mortem to another sector of the aristocracy. This comes to fruition forty years later, ${ }^{139}$ thus, a clientelar practice (land endowment to compensate fosterage services) contributes to the formation of church patrimony.

The participation of servants in the fosterage relationship and the special esteem in which they are held by their lords, as seen in Njal's saga, help us understand the gifts of land to dependents with whom aristocrats have established clientelar bonds. While in the first gift Velite is subject to providing labour services, in the second gift (the count's through Alfonso vi) no rents are mentioned, which allows for the interpretation of the covenant as a promotion compensating Velite for his fosterage of the count; indeed, Velite will be able to freely dispose of the lands he were to obtain through purchase or other methods, ${ }^{140}$ which sets him apart from the servile condition. ${ }^{141}$ The promotion of unfree persons who have acted as fosterers is a common occurrence: in 1155 countess Elvira Velázquiz grants freedom to the family who raised her, stipulating they can 'go wherever they want' and not pay tribute (a nullo homine obsequium reddant)..$^{142}$ The donations granted to collazos, generally considered servile dependents, who reciprocate the gift of lands with swords, ${ }^{143}$ can also be understood in similar terms; it has also been suggested that this word derives from collacteus, whose primitive sense is associated with artificial kinship. ${ }^{144}$

In these examples the covenant of benefactoria is a formula for the promotion of dependent individuals with whom the aristocracy maintains an ambivalent bond ranging from the demand for rents to the compensation for other types of services. In this sense, the predominance of the feudal mode of production is compatible with the persistence of archaic customs among members

139 Herrero de la Fuente 1988b, doc. 1155 (1107).

140 Herrero de la Fuente 1988a, doc. 675 (1068): ut habeat ipsa corte cum omni hereditate que ad ipso solare pertinet; et quantum super hoc ganauerit uel plantauerit uel hedificauerit uel etiam comparauerit, liberam habeat possidendi potestatem.

141 Pérez Prendes y Muñoz de Arraco 1988, Fuero de León (o), tit. X. On this norm, see Sánchez Albornoz 1976b, pp. 221-49.

142 Muñoz y Romero 1847, p. 162: Et dedit mihi illa comitesa dona Gelvira de quam fuit criatione, facio vobis cartam ingenuitatis et libertatis, ut redeunde, vivendi, laremque fovendi vitam vestram ubi volueritis.

143 Herrero de la Fuente 1988b, doc. 887 (1092).

144 According to Estepa Díez 2003, p. 52, those who gave this kind of gifts would actually be milites. This is hard to accept in the case of Velite Álvarez, to whom labour services were imposed. 
of the aristocracy, who should not be viewed as external agents of the social practice they modify but rather as social actors who still partake in some of its contents which they partially negate.

In some cases, the land recipient has been brought up by the patron. In 1059, Diego Pátriz accepts lands from his foster-father, who is a member of a comital family. The text specifies that he will not be allowed to serve another lord as long as his patron is alive. ${ }^{145}$ More than thirty years later, Diego Pátriz cedes the land to the monastery of Sahagún for the salvation of his soul and to free himself from all 'human service', ${ }^{146}$ which means his sons, who retain usufruct, will be subject to seigneurial exploitation. Our client, who deems that the obligations often imposed by the abbot are very stringent - a perspective that sets him apart from the relation of serfdom - requests that his children be afforded some consideration when they are taxed, and that they be allowed to serve as knights if they have a horse. ${ }^{147}$ It follows that this must have been the service he provided for his own patron, and that he has not been able to knight his sons, which leads us to deduce that he is of peasant origin. The example illustrates the precarious situation of some of the parties in these agreements (peasants eventually equipped with horses) and the loss of their economic autonomy over the course of two generations, a tendency that must be considered in conjunction with that of social advancement. The degradation of the political autonomy of the clients characteristic of the evolution of these bonds, is combined with mechanisms of accumulation specific to another sector of the aristocracy (the absorption of lands through grants pro anima), just as in the case of the count's foster-father examined above, which suggests that the evolution of clientelar relations has been subordinated to the global reproduction of the dominant class.

Fosterage bonds, as we have seen in Njal's saga, are binding. This content favours the consolidation of stable links and could explain the lasting quality of the covenants, an aspect that contradicts the theoretical ability to change allegiances. Witness the case examined above, where the client serves his

145 Herrero de la Fuente 1988a, doc. 606 (1059): Facio cartulam donationis ... de hereditate mea propria quam habui ex patre meo comite Guttier Afonso ... Do et dono ipso solare tibi suprascripto Diaco propter creacionem quam sub Deo creaui te et propter seruicium bono ... Tantum in diebus nostris non permitto te seruire cum illo alio domno.

146 Herrero de la Fuente 1988b, doc. 909 (1093): non solum pro remedio anima mee, verum etiam et ut ego sim liber in omnia vita mea de omni servicio humano.

147 Herrero de la Fuente 1988b, doc. 909 (1093): Et filii mei non subiugati tam stricti sint in servicio sicut ceteri, sed ut tantummodo ponant XIIm dies in anno ad servicium domni abbatis; quos si habuerit kavallos serviant sicut kavallarii. 
patron and foster-father for life, not only by virtue of the land he is gifted but also by virtue of a bond of family loyalty obliging him to assume his patron's enmities and remain at his service. This double commitment is palpable in the services he calls 'human services' that he has provided for his foster-father for over thirty years, as distinguished from the tribute demanded by the abbot of Sahagún, which he considers a form of subjection (et filii mei non subiugati tam stricti sint in servicio sicut ceteri).

A privilege granted by Alfonso VI to the monastery of Samos prohibiting milites from having vassals per amatiatum sive criandum and punishing the locals who raised the children of milites confirms the spread of fosterage bonds during the eleventh century. This suggests that the inhabitants resorted to this bond to avoid their obligations toward the monastery, ${ }^{148}$ and that it was habitual for milites and peasants to establish dealings of this kind, which the abbot suppresses in his attempt to impose his lordship over the place. From this we can deduce that the fosterage bond is distinguishable from a relation of exploitation, even when the child-giver and the feudal lord are designated with the same word (qui se amo fecerit vel qui se in alium dominum transtulerit, ad dominum monasterii reducat), which supports the notion that it is derived from practices of the peasant mode.

The type of relationship established between families linked by fosterage bonds also explains why clients become involved in their patrons' disputes. The twelfth-century regulations address this issue: a decree of Alfonso IX forbids lords from seizing property belonging to clients of other lords due to debts or enmities that the interested parties could hold against their patrons unless the clients were armed with lances. ${ }^{149}$ It follows from this that military support was the norm among clients even if they were not fully equipped, and that they were vulnerable to the aggression of their patrons' enemies even if they did not participate in military activities. The fact that seigneurial behaviour toward someone else's clients is regulated points to a qualitative change, given that it transfers the problem from the sphere of conflict between families, which implicated clients in their patrons' disputes, to the sphere of the conflict between lords whose main bone of contention are the clients of rival lords and their possessions.

148 De Hinojosa 1919, p. 96: Et si aliquis filius militis ibi nutritor vel aliquis ibi se posuit sub alio domino nisisub domino samonensis, mando isti homini meo, quod filium militis, qui in cautos samonensis nutritor, foras de cautos eiciat.

149 De Hinojosa 1919, p. 148: quod nullus pignoret benefactoriam pro debito vel inimicitia domine benefactorie, nisi ipse beneficiatus fuerit lancearius. 
The link between the benefactoria and the practice of fosterage is confirmed in documents from the later Middle Ages related to behetrías (lordships derived from relations of benefactoria) which regulate aspects related to intra-lordly conflict: a fifteenth-century ordinance urges neighbours to defend the ruling lord from the interference of other powers; it stipulates that should a neighbour die in these circumstances, the local council shall raise his children. ${ }^{150}$ This late example reflects the residual survival of peasant practices voided of substance, where the involvement of neighbours in their leaders' disputes no longer expresses a clientelar bond but the exercise of political rights on the part of the lord, which oblige the locals to fight in the ranks of the magnate whose lordship over the area is at stake.

\section{The Power to Choose a Lord}

Instability is a characteristic feature of the leaderships in peasant mode societies. In Iceland, each free man who is the head of a household must be attached to a go $\partial i$, whom he can both choose and abandon. The go $i^{\prime}$ 's authority, regardless of the heritability of the position, depends on his ascendancy over the men attached to his leadership, who can withdraw their allegiance and attach themselves to another chieftain. ${ }^{151}$ We have reviewed an example from Eyrbyggja saga, when Thorolf transfers his allegiance to Snorri goði. Njal's saga provides a paradigmatic case: Mord, who has inherited his position as goð $i$, loses all his followers to Hoskuld (Njal's foster-son); the site where the assembly used to be held, normally equipped with makeshift structures, is in a state of neglect because when changing allegiances the men have shifted to the location where their chosen chieftain holds the assembly. ${ }^{152}$ The community has real existence when the individual proprietors gather in an assembly; ${ }^{153}$ concomitantly, the authority has real existence only when the leader enjoys the effective support of the individual proprietors: when losing his followers, Mord also loses the powers of the chieftaincy over which he holds hereditary rights.

The texts regulating benefactoria relations refer to the faculty to elect a lord for the subscribers of a covenant, the recipients of a fuero or those who accept

150 Oliva Herrer 2003, p. 201.

151 On chieftancies in medieval Iceland, see Chris Wickham's chapter in this book. See also Jón Viðar Sigurðsson 1995, p. 155; Helgui Porláksson 2005, pp. 139-40; Byock 2001, pp. 119-20 and $126-8$.

$15^{2}$ Njal's saga, ch. 107.

153 Marx 1964, p. 78. 
gifts of land. This faculty is addressed in the legislation. ${ }^{154}$ In general, the covenants of eleventh-century Castile and León do not contain restrictions regarding the clients' bonds: the typical expressions are vadas cum eo ubi volueris, or ad unos aut alios domnos, qui tibi bene fecerit, etc. These formulae reflect an acknowledgement of the land recipient's free condition (or his promotion to a free condition), seeing as one of the attributes of freedom is the ability to change allegiance.

In a majority of the charters, the subscriber of this type of covenant can in theory abandon the chosen lord and is free to lend his support to different members of the aristocracy. ${ }^{155} \mathrm{He}$ can choose, for example 'a king, a count, a bishop, an abbot, in Castile, in Galicia,'156 that is to say, he will pick his lord from the pool of the aristocracy and without geographical limits. In other charters the aristocratic spectrum is identified with the two main lineages, that of Banu Mirel and that of Alfonso Díaz. ${ }^{157}$ Although this limitation restricts the number of potential patrons, in theory those who present certain qualities are eligible, as happens in peasant societies (in Iceland, for example, the men choose a chieftain from among a limited number of goðar), which acknowledeges that clients hold a certain political protagonism. This criterion undergoes a shift when patrons take the side of one of the two main lineages on referring to the election of a lord, thus constraining significantly the spectrum of possible political alliances for their clients. ${ }^{158}$ Finally the election of a lord will be restricted to the patron's lineage. ${ }^{159}$ In certain cases the patrons restrict their clients' bonds to specific persons of their family group: Urraca, a member of the lineage of Alfonso Díaz, stipulates that the individual to whom she

154 Pérez Prendes y Muñoz de Arraco 1988, Fuero de León (o), tit. XIII: Praecipimus adhuc, ut homo qui est de benefactoria, cum omnibus bonis et haereditatibus suis eat liber quocumque voluerit.

155 Herrero de la Fuente 1988a, doc. 566 (1054), 624 (1063), 634 (1063), 676 (1068), 702 (1071), 713 (1072), 719 (1973); Herrero de la Fuente 1988b, 737 (1074), 778 (1080), 788 (1080), 795 (1081), 818 (1085), 824 (1086), 825 (1086), 887 (1092), 1015 (1097), 1086 (1102), 1173 (1085); Fernández Flórez 1991, doc. 1189 (1113), 1198 (1117), $125^{2}$ (1133); Ruiz Asencio 1987, doc. 894 (1031); Ruiz Asencio 1990, doc. 1233 (1084).

156 Herrero de la Fuente 1988b, doc. 804 (1083).

157 Herrero de la Fuente 1988b, doc. $75^{2}$ (1077).

158 Herrero de la Fuente 1988b, doc. 1077 (1101): Vadatis cum illo inter filios et neptos de Vani Mirelliz; doc. 811 (1084): inter casata de Vani Mirel ad quale tibi melius fecerit; Ruiz Asencio 1990, doc. 1192 (1073): et vadeas cum eo medio die et media ora inter Vani Mirel qui tiui melior fecerit tu et filiis tuis et neptis tuis vel viisneptis.

159 Herrero de la Fuente 1988b, doc. 1096 (1103), 1125 (1105), 826 (1086), 893 (1092), 959 (1095); Herrero de la Fuente 1988a, doc. 549 (1051). 
has ceded lands, Rexendo, will be allowed to choose among the children and grandchildren of two of her brothers, the daughters of one sister, and the men of the monastery of Sahagún. ${ }^{160}$ According to the data available on this family, Rexendo will be able to choose from among twenty people. This evolution tending to the limitation of the clients' allegiances is also evidenced when patrons secure services until their deaths. ${ }^{161}$

The imposition of serving one lord for life and remaining within the orbit of one family reflects the infusion of new meaning into the peasant practice, which tends to place itself at the service of feudal logic while preserving the vocabulary of liberty. The relative independence of the remaining free peasantry in a feudalised context accounts for the preservation of the formula regarding the election of the lord and also the successive curtailments it undergoes in practice, which are progressively incorporated into the texts. This process is enabled by some contents of the peasant practice. The fosterage bond, for example, facilitates the patron's tendency to restrict the circle of eligible lords to his family members. When the patron is both lord and child-giver, foster-son or foster-father, the essential content of the fosterage bond stimulates the formation of permanent clienteles and contributes to the degradation of the political autonomy of free proprietors. It follows that some aspects of the dynamics of the peasant mode can promote an evolution to more stable bonds, which contributes to the readaptation of social practice to the requisites of aristocratic dominance.

The tendency to restrict the election of the lord to members of the patron's own lineage is nascent during the eleventh century and dominant in the twelfth century, when benefactoria relationships no longer refer to individuals but to communities as a whole, which, for their part, have constituted themselves legally as such as inferred from the references to local authorities. The inhabitants of Andaluz, for instance, will choose a lord from among the kinsmen of the count who has granted them a set of norms. ${ }^{162}$ The election of the lord has now become a collective practice: the community will have to choose

16o Herrero de la Fuente 1988a, doc. 620 (1062): Et post mortem meam uadas inter filios et neptos de fratribus meis domno Monio et domno Gutier aut inter filias de domna Adosinda, soror mea, nominatas Goto et Monia, aut a domnos de Sancto Facundo, uel qui tibi melior fecerit.

161 Herrero de la Fuente 1988a, 606 (1059), 620 (1062), 721 (1073); Herrero de la Fuente 1988b, doc. 952 and 953 (1095), 728 (1074).

162 Fuero de Andaluz: hayan behetría entre mis fijos e mis nietos e en todo mi linaie, cited by Sánchez-Albornoz 1976b, p. 209. This fuero is a translation from the original Latin version to Romance, available at: http://es.wikisource.org/wiki/Fuero_de_la_Comunidad _de_Villa_y_Tierra_de_Andaluz_de_1098. 
the one preferred by the majority. ${ }^{163}$ The higher powers' interest in disciplining the political bonds of the community is evidenced in the twelfth-century legislation: in 1104, count García Ordóñez prohibits the coexistence of diverging alliances in Fresnillo, forcing the locals to choose from among one of his descendants. ${ }^{164}$ The same preoccupation is observed in the laws imposed on the people of Escalona in 1130, which tend to standardise the allegiances of the neighbours and restrict them to the family of the local dominus. ${ }^{165}$ The fuero of Belbimbre of 1187 attempts to suppress the establishment of multiple alliances in the same village by stipulating that the locals should not submit to more than one lord. ${ }^{166}$ The same law allows milites to attach themselves to a lord of their choosing, ${ }^{167}$ which confirms that the ability to choose one's lord is associated with freedom, and that in the twelfth century this concept is becoming exclusively identified with a privilege.

\section{The Practice of Hospitality and the Requirement of Tribute}

Contributing to the support of the itinerant court is a public burden, just as military service and attendance to the assembly; it is likely that the supply of victuals for the lord when he passed through a locality constituted an informal service not expressly mentioned in the texts. This practice is consistent with services rendered by the clients, which we have understood as derived from the forms of reciprocal exchange typical of the peasant mode. In one of the Sahagún documents, the gift of lands is repaid with bread, wine, clothes and shoes, ${ }^{168}$ which could have symbolised hospitality, in the same way that horses

163 Sánchez Albornoz 1976b, Fuero de Andaluz: Et ser todos dun sennor et do fueren la mayor partida que vayan los otros.

164 De Hinojosa 1919, p. 47, Fuero de Fresnillo, tit. 13: Et non intretis in temptacione nec particione, sed abeatis benefectria cum vestras causas ad filiis nostris vel neptis seu ad qualem vobis placuerit aut meliore fecerit, ut ipsi serviatis.

165 Muñoz y Romero 1847, p. 485: Vos vero in diebus nostris non eritis divisi et post nostram mortem et filiis nostris cui volueritis et melior vobis fecerit, ipse servite cum omnia vestra bona.

166 Martínez Díez 1982, p. 179, Fuero de Belbimbre y sus cuatro aldeas, year 1187, tit. 9: Omnes habitatores ... unius tantum domini prestamerii adhereatis, et nulli liceat uos per partes diuidere, aud plurium dominorum dominatui subicere.

167 Martínez Díez 1982, Fuero de Belbimbre y sus cuatro aldeas (1187), tit. 5: Preterea omnibus uobis qui milites fueritis in Beneuiuere et in predictis quatuor barriis indulgeo et concedo quod nullam facenderam pectetis, et habeatis dominos quales habere uolueritis et domos uestras liberas possideatis.

168 Herrero de la Fuente 1988b, doc. 824 (1086): Accepimus de uobis in pretio, in pane et in vino et in vestire et in calcare, apreciatura in CL solidos. 
and swords symbolised military service. The possession of military tenancies carries the obligation to offer meals to the lord when he passes through the territory. ${ }^{169}$ According to the literature on this subject, hospitality services are a part of the duties of those who take in foster-children and receive lands in exchange for their loyalty. ${ }^{170}$ These are the services referred to in the documents on primitive behetrías, according to which the knights 'ate the victuals they found.' ${ }^{171}$

The transition from military obligations and voluntary contributions of food to the payment of agrarian rents has been considered in relation to the emergence of feudal relations of exploitation. Carlos Astarita has proposed that this transition is reflected in imprecise formulae in which the tribute is not yet conceived of as a regular exaction, nor has it acquired yet a stable composition; instead there is a prevalence of demands whose manner takes into account the will of the inhabitants (quantum poterint ad comite, etc.). ${ }^{172}$ In the tribal societies of Northern Europe, the transition to the feudal mode is seen, according to Wickham, in the mutation of the 'tribal' tribute, a light contribution, into rents that are more complex, more onerous and susceptible to commercialisation; another expression of this transition to relations of exploitation is the demand for hospitality tributes by a growing number of persons. ${ }^{173}$ In what concerns our analysis, the transformation of the services rendered by clients into agrarian rents represents the full incorporation of these individuals and their social forms into the dominant feudal dynamic of the area, which constitutes one aspect of the general process of expansion of feudalism over free spaces.

The demand for rents of a definite kind appears associated with the benefactoria in documents from the early twelfth century. In 1125, the norms imposed on the people of San Cebrián, who are allowed to choose their lord, ${ }^{174}$ establish the amounts due as rent. The villagers are exempted from some taxes and the fine for homicide is cut in half; in exchange, they must hand over thirty loaves of bread, a certain amount of wine, and one side of bacon or one ram as long

169 García de Valdeavellano 1955 (Apéndice documental, doc. XII): unum prandium semel in anno de debito in omnibus expensis, si contigerit me facere transitum per terram illam.

170 Parkes 2006, p. 363.

171 López de Ayala 1991, p. 42 (Crónica de Don Pedro I, II, ch. XIV).

172 Astarita 2003-6, p. 34 .

173 Wickham 2005, pp. 344-9.

174 De Hinojosa 1919, Fuero de San Cebrián, year 1125: Do vobis benefetria ... ut tornetis ad qualem seniorem volueritis quem villa mandauerit. 
as they are able to obtain these products from their labour. ${ }^{175}$ This condition could reflect a formative stage of the new social relations (the imposition of burdens on free people), in which the tribute, compulsory and defined as it is, preserves on paper its character as a more or less flexible supply of food. The delivery of agrarian surpluses is formally presented as a reciprocal exchange: the lord must treat the council to a meal. ${ }^{176}$ It is noteworthy that although a tribute is being imposed on direct producers, hospitality is ostensibly an obligation of the lord, which allows for a transfer of surplus while preserving the formality of reciprocity. Just as in the case of previously examined practices, the dominant feudal logic of the area introduces new content while leaving intact the appearance of the custom, although in this case, in contrast to the early eleventh-century covenants, the archaic references are marginal, and the new contents reflect the full incorporation of these social forms into the feudal mode of production. In the locality of Andaluz, for instance, the rents that the locals will pay are established; the villagers can choose a lord from among the kinsmen of the count who has granted them a fuero; he who is chosen shall hold a feast for the community. ${ }^{177}$ The continuance of food services on the part of the lord and the feasts he holds for the villagers who have chosen or accepted him as lord could have their precedent in the collective celebrations of peasant societies. In Laxdcela saga this practice is related to the need of legitimation: the feast that Olaf the Peacock, a renowned go $i$, holds for a large crowd of people in memory of his late father, who favoured Olaf in the distribution of the inheritance despite his being an illegitimate son, is aimed at Olaf's public validation as truly deserving his father's favour and the support the latter enjoyed. ${ }^{178}$

In the twelfth century these public feasts are replaced with money payments from the lord. The fuero of Lara of 1135 , for example, obliges the people to deliver meat for the lord and his retinue when they visit the locality; the local authorities shall appraise the victuals and the lord shall pay for them, otherwise the villagers can deprive him of the food without being penalised. ${ }^{179}$ Here we

175 De Hinojosa 1919, Fuero de San Cebrián, tit. 15: Si colegerit de sua heriditate det istum forum, et si non colegerit non det ... si habuerit porcos aut oves det, et si non habuerit non det.

176 De Hinojosa 1919, Fuero de San Cebrián, tit. 12: Et dominus det concilio ... unum iantarem.

177 Sánchez Albornoz 1976b, Fuero de Andaluz, 1.

178 Laxdcela saga, ch. 27.

179 Martínez Díez 1982, p. 141, Fuero de Lara, year 1135, tit. 38: Quando uenerit dominus Lare in illam ciuitatem, accipiat ille iudex cum suo saione karne por espesa, et aprecient illam karnem homines de conceio, et det fidiatore [in blank] merino et pectet eum; nisi non dederit fidiatore illo merino, tollat eum et non habeat calumnia. 
observe on the one hand the conversion of feasts offered by the lord into money payments, and on the other hand the conversion of the spontaneous hospitality of the villagers into an obligation.

The reference to hospitality service in twelfth-century texts, which regulate the election of the lord or refer to this right, confirm that it was common practice to provide hospitality for the lord, and that it was beginning to be regulated during the period in question. This regulation sets limits pertaining to the group of service providers, which tend to be identified with peasant labourers: the 1135 fuero of Lara exempts those who own a horse and clergy from the obligation to provide shelter, ${ }^{180}$ the fuero of Villadiego exempts knights and priests; ${ }^{181}$ the set of norms imposed on the inhabitants of Villavicencio in 1156 frees knights from the obligation to house the lord. ${ }^{182}$

This legislation by which the obligation to provide shelter falls only on the farm labourers coexists with another in which the will of the latter is ambiguously contemplated, and at the same time it becomes apparent that hospitality services are being demanded by force. In the fuero of Escalona of 1130 we read: posadas perforcia, non donent. ${ }^{183}$ In a study on the Latin vocabulary in Carolingian documents, Kuchenbuch suggests that the verb donare, which is rarely used and associated with mansi ingenuiles, could be an indicator of the higher status of the people from whom tribute is being demanded, and that its use could reflect new impositions. ${ }^{184}$ According to this perspective, our example could reflect the tendency to impose hospitality services on people who had not previously been subjected to taxation. The inhabitants of Villavicencio must also 'donate' a certain amount of food and 'no more, unless they do so of their own accord'. 185 The ambivalent wording in the demands for this type of encumbrance from free people, which references both the will of the villagers and

180 Martínez Díez 1982, Fuero de Lara, year 1135, tit. 44: Quando uenerit dominus Lare in illam ciuitatem, per mano de illo saione accipiant illos caualleros posadas, et non posent in casa de qui cauallo ouiere, necque in casa de uidua necque in cas a de clerico, nisi fuerit clericus.

181 Martínez Díez 1982, p. 137, Fuero de Villadiego, year 1134, tit. 13: Et in casa de cauallero neque de clerigo neque de vidua non posset nullus homo.

182 Muñoz y Romero 1847, p. 176, Fuero de Villavicencio: Et qui pausare voluerit in illa villa, pauset in suis et postquam casas de suos homines fuerint plenas pausent per alios, set non in casa de caballero.

183 Muñoz y Romero 1847, p. 487, Fuero de Escalona.

184 Kuchenbuch 2003, pp. 206-9.

185 Muñoz y Romero 1847, Fuero de Villavicencio, year 1156: Donet pro suo foro decem panes, et media kanatellam de vino, et uno quarto de carnero, et duos lombos non magis, nisi sua sponte. 
seigneurial violence, is observed in the fuero of Belbimbre of 1187, which stipulates that the lord shall not break into the judge's house ${ }^{186}$ and contemplates the wishes of the host after three days of compulsory housing. ${ }^{187}$

The regulation of hospitality services involving the obligations of both lords and peasants as well as lordly abuse is more fully developed in laws related to lordships of behetría which spell out in detail the manner in which taxpayers must provide food, clothing and accomodation to their lords and the payments the latter must render for the victuals, which must be consumed in situ. ${ }^{188}$ The texts regulating these services allude to certain older legislation whose existence historians have verified and dated to the period between 1184 and $1185 .{ }^{189}$ This legislation, whose spirit is consistent with the laws of that period, may be derived from the need to regulate the people's relations with the noblemen among whom they picked a lord, probably members of the lineage with more influence in the area, who attempt to formalise their condition as potential lords and materialise in defined rents their right to be chosen as such.

During the twelfth century, the hospitality services, which everyone must render on principle, tend to become concentrated in one social sector defined by its exclusion from privilege and to be demanded by an increasing number of persons; the regularity and composition of the service are established albeit preserving the ceremonial aspect of reciprocity on the part of the lord, whose prodigality is limited first to public feasts and later to money payments to the service providers. This conventional generosity of the lord could be linked to his symbolic legitimation as tax levier, which comes into being through practices that are formally analogous to the ones that secured his leadership in the pre-class society.

186 Martínez Díez 1982, Fuero de Belbimbre y sus cuatro aldeas (1187), tit. 17: In domo iudicis nullus dominus uiolenter hospitetur.

187 Martínez Díez 1982, Fuero de Belbimbre y sus cuatro aldeas (1187), tit. 10: In quacumque domo prestamerum hospitali contingerit ... ultra trium dierum spacium contra uoluntatem hospitis sui prestamerus solo uno momento moram non faciat.

188 Códigos españoles concordados y anotados: Fuero Viejo de Castilla and Ordenamiento de Alcalá de Henares de 1348 (hereafter FVC and OA). Lords must pay what they have consumed (FVC, I, VIII, 1); local inhabitants must report themselves, otherwise they will be punished (FVC, I, VIII, 2); lords will demand hospitality, foodstuff and clothing (FVC, I, VIII, 3); straw for their horses and wine (FVC, I, VIII, 1), firewood (FVC, I, VIII, 4), and vegetables (FVC, I, VIII, 5); the whole process shall be supervised by boni homines in order to prevent lordly abuse (OA, XXXII, XXVIII).

189 OA, XXXII; Barbero and Loring García 1991, pp. 27 ff. 


\section{Conclusions}

In contrast to the criterion employed by Wickham to conceptualise exploitative modes of production by which they are reduced to forms of surplus extraction, his concept of the peasant mode accounts for the elements intervening in the productive process, for relations of production and property, for the logic of social functioning and the conditions for its genesis, reproduction and transformation. The elements deriving from the disposition of the product (low intensity of labour, reciprocity) are consistent with those of 'primitive' societies in different historical contexts. It follows that productive forces, and even relations of production, do not singularise a mode of production. A mode of production, according to the Formen, implies a form of property at its base. From this perspective, the peasant mode as it appears in Western Europe can be basically identified with the Germanic mode, which is why it could be conceived of as a re-elaboration of the latter devoted mainly to developing aspects of its functioning laws. These elements were assessed on the analytic level of the social formation, since they allow for the characterisation of the forms of articulation between the aristocracy and free communities, and in our case highlight the process of subordination of the latter to the feudal mode of production.

This process undergoes different stages characterised by the formal preservation of peasant mode practices and the progressive negation of its contents or the subordination of the practice to already existing mechanisms of accumulation. Peasant practices, in turn, contain elements that favour the advance of the feudal logic. The gifts of lands in return for services of mediation and representation, a tool for status negotiation in peasant societies, become functional to the formation of aristocratic patrimony; the practice of fosterage, founded on reciprocity, contributes to the stabilisation of bonds. To the extent that this is achieved and political structure becomes less dependent on the conformity and support of peasant sectors (or, as Engels would put it, to the extent that social functions become independent from society), the aristocratic logic finds more space to deploy itself more openly. This is evidenced in the spread of oppressive practices on free people, which could explain the mutation of spontaneous contributions of victuals into hospitality rents that the lords seize by force in the period prior to their regulation. Thus, the condition of possiblity of seigneurial violence that historians associate with the rise of banal lordship would have been an earlier period of symbolic violence and reworking of the peasant practice during which stable bonds of subordination were consolidated.

The transformation of free clients into tenants subject to rent or feudal vas- 
sals is one of the forms of expansion of feudalism. Since in our case we begin with a social formation in which the aristocracy coexists with autonomous nuclei, the advance over these nuclei by means of the recruitment of vassals among the peasantry or the conversion of free clients into taxpayers reflects the dissolution of peasant societies and therefore the transition from one mode of production to another. This transition can be explained by the prevalence of individual private property susceptible to disposition and fragmentation which characterises the peasant mode at its base and underlies the social practices reflecting its social functioning. These social practices feature transactions involving land, which in turn implies the individual's emancipation from community and kin. Furthermore, the social functioning of the peasant mode, based on the logic of the gift, constrains the possibilities of accruing wealth and requires costly strategies on the part of those who attempt to build or maintain a position of power, which must rest on material concessions, respect for custom and mechanisms invoking the ideology of reciprocity. Even though in societies where feudalism has developed the peasant mode holds a subordinate position in the social formation, its principles condition the actions of the aristocracy. This delays the expansion of the new social relations and determines its modalities, which we have characterised as gradual and ambivalent.

Both the form of property and the social relations of the peasant mode carry evolutionary tendencies (to dispossession in the former, and to conservation or slow pace of accumulation in the latter) that combine in the historical process, as we have demonstrated in the empirical study of clientelar relations in Northern Spain, whose transformation into exploitative forms drags on for over a century and involves strategies of concession toward the free peasantry. These tendencies depict a dynamic proper to the peasant mode which is not contingent but derived from the structural traits of this mode of production: it is contained in the asymmetric substance of the gift and the potentialities of individual property, which undermine egalitarianism. This dynamic, as we have seen, can explain the structural transformations. 